\title{
機能的印象材の物性に関する基礎的研究
}

\author{
九州菌科大学第 1 補緅学教室（指導：豊田静夫教授） \\ 帆䈍郷 \\ (本論文の要旨は昭和53年度九州曾科学会総会, 昭和54年度日本補緅菌科学会九州支部会および昭和54年度 \\ 九州歯科学会 7 月例会において発表した)
}

\section{Fundamental Studies on Physical and Mechanical Properties of Functional Impression Materials}

Goichi Howashi

First Department of Prosthetic Dentistry (Director : Prof. Shizuo Toyoda)

Kyushu Dental College, Kitakyushu, Japan

\begin{abstract}
At present time, the functional impression materials have been willingly used for performing the tissue treatment and taking the dynamic impression. However, the physical and mechanical properties of these materials in oral cavity are not elucidated sufficiently as yet. So the author measured the variation of the coefficient of viscosity and torsional shear modulus with time of the mixture mixed in various ratios at $23^{\circ} \mathrm{C}$ and $37^{\circ} \mathrm{C}$ for five commercial functional impression materials (Hi-soft, Hydrocast, Tri-plastic, Visco-gel, Tempo). In addition, the swelling of powder to liquid was examined by microscope and the water absorption of the functional impression material (powder-liquid mixture) was investigated by using gas chromatograph.
\end{abstract}

The results obtained were as follows:

1. The working time of Hydro-cast, $\mathrm{Hi}$-soft and Visco-gel was longer than that of Tri-plastic and Tempo, and the variation of torsional shear modulus and the coefficient of viscosity within working time were smaller.

2. The working time of the materials used was varied by mixing temperature and mixing ratio $(\mathrm{P} / \mathrm{L})$. When the temperature of mixture rose and ratio $(\mathrm{P} / \mathrm{L})$ increased, the working time was shortend.

3. The torsional shear modulus at $60 \mathrm{~min}$ from start of $\mathrm{mix}$ was $49.7 \times 10^{4} \mathrm{dyne} / \mathrm{cm}^{2}$ for Tri-plastic, $41.5 \times 10^{4} \mathrm{dyne} / \mathrm{cm}^{2}$ for Visco-gel, $22.4 \times 10^{4} \mathrm{dyne} / \mathrm{cm}^{2}$ for Hydro-cast, $21.0 \times 10^{4} \mathrm{dyne} / \mathrm{cm}^{2}$ for Tempo and $17.5 \times 10^{4} \mathrm{dyne} / \mathrm{cm}^{2}$ for $\mathrm{Hi}-\mathrm{soft}$.

4. The materials used in this investigation lost ethanol and absorbed water by soaking in distilled water.

\section{I は じめに}

有床義菌，とくに全部床義菡の製作にあたっって，義

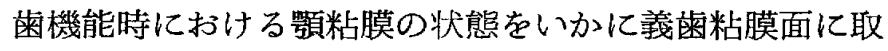
り入れるかがその義雨の良否を決定する重要な一要因と なる。 
顎粘膜は，口腔の部位により著しくその被圧縮性を異 にし1-3)，機能時之非機能時では全く様相が異なるため， 従来より加圧印象を是とするものと無圧印象を是とする ものの間にも論議がたえない4ー8)。

佐久間9”ば適合のよい，十分使いこなされた義霜装 着者の䅡粘膜にはわずかな圧痕が認められるが，てれは 加圧による状態でも，また無圧の状態でもなく，顎粘膜 がさまざまな荷重を受けて変形と回復を繰り返すうち に，クリープとその回復とが平衡状態になった結果であ る”と述べている。

この䫟粘膜の状態を得ることが無嵐顎印象の現想とす るならば，従来の印象法ではこの状態を十分に再現する ことはできない。

また適合不良の義歯を長期間装着していた患者の額粘 膜は非生理的に圧迫変形されていることが多いが，1012）新義歯作製時には，これらの非生理的に変形した顎 粘膜を生理的な状態にまで回復した状態で印象採得をし なくてはならない．近年開発された機能的印象材ならび に術式は，乙れらの問題点を解決する上で効果的な材料 として注目されている．乙の印象材は, 練和直後は非常 に流動性に富むが，数分後には粘弾性のあるゲル状物質 となり，乙の粘弾性的性質が数時間あるいは数日間持続 する.乙の間に非生理的に圧迫変形されていた䪽粘膜は 健全な状態にまで回復し，いわゆる組織調整と機能圧下 の印象を効果的に行うことができると考えられており数 多くの報告がなされている13-24)。

しかし，乙の印象材の臨床的な応用には，それを用い る臨床家の経験と勘によるとてろが多く，必ずしむ確実 な方法ではない，ての材料を用いて，より確実で効果的 な印象を行うには，被印象体である顎粘膜の粘弾性的性 質 25-27)ならびに印象材自体の物理的性質を究明する必
要がある。

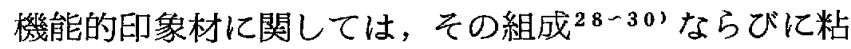
弾性等の物理的性質 ${ }^{31-41)}$ 亿ついての研究はあるが，不 明な点も多く，まだ臨床的操作の上に十分活かされてい るとは言えない。

著者は,機能的印象材を用いて,印象採得を行う場合， 比較的短時間内で，その効果が発揮されるものと考え， その間の経時的な粘弾性挙動を究明した。

\section{II 実験材料と実験方法}

材料：本実験に使用した材料は，現在市販されている機 能的印象材, Hi-soft, Hydro-cast, Tri-plastic, Visco-gel，Tempo（以下それぞれ順に HS，HC, TP，VG，TM と略記する) の5 種類である. その製 造会社名，製造番号およびメ一力指示の重量粉液比につ いては Table 1 に示す.

\section{実験 1 (粘度の測定)}

1) 測定装置

実験に使用した測定装置は $\mathrm{E}$ 型粘度計（コーン・プレ 一ト式，東京計器社製）にST 型アダプターを装着した もので $0 \sim 1.86 \times 10^{7} \mathrm{cp}$ までの広範囲の粘度を少量の 試料で測定できるようにしたものである．装置ならびに 機構については Fig.1，2 に示す。また粘度計の作動 原理図はFig. 3 亿示す.

この粘度計は, 同期モータの回転を変速機構およびべ ルトを介して目盛板に伝える，目盛板にはスプリングを 介してロータが取付けられており，目盛板が回転すると ロータも同じ速度で回転する. サンプルカップ中に試料 を入れ，モータを回転させると，その試料の粘性のため にロータに抵抗が生じてスプリングがねじられる．乙の ねじれはロータに㗢く試料の粘性トルクとスプリングの

Table $1 \quad$ Materials used

\begin{tabular}{|c|c|c|c|}
\hline \multirow{2}{*}{ Material } & \multirow{2}{*}{ Manufacturer } & \multirow{2}{*}{ Batch No. } & $\begin{array}{l}\text { Mixing ratio recommended } \\
\text { by manufacturer }\end{array}$ \\
\hline & & & Powder $(g):$ Liquid $(g)$ \\
\hline $\mathrm{Hi}-$ soft & Shofu $\underset{\text { (JAPAAN) }}{\text { Dental Mfg. Co., Ltd. }}$ & 107836 & $1.7: 1.0$ \\
\hline Hydro-cast & $\underset{\text { Kay See Dental Mf.S.A.) }}{\text { Mf. Co., Ltd. }}$ & 21378 & $0.8: 1.0$ \\
\hline Tri-plastic & $\begin{array}{c}\text { Opotow Dental Mfg. Co., Ltd. } \\
(\text { U.S.A. })\end{array}$ & 6353013030 & $1.4: 1.0$ \\
\hline Visco-gel & $\begin{array}{l}\text { Amalgamated Dental } \\
\text { (ENGLAND) }\end{array}$ & WE7 WC7 WE & $1.3: 1.0$ \\
\hline Tempo & Lang Dental Mfg. Co., Ltd. & 92377 & $1.3: 1.0$ \\
\hline
\end{tabular}




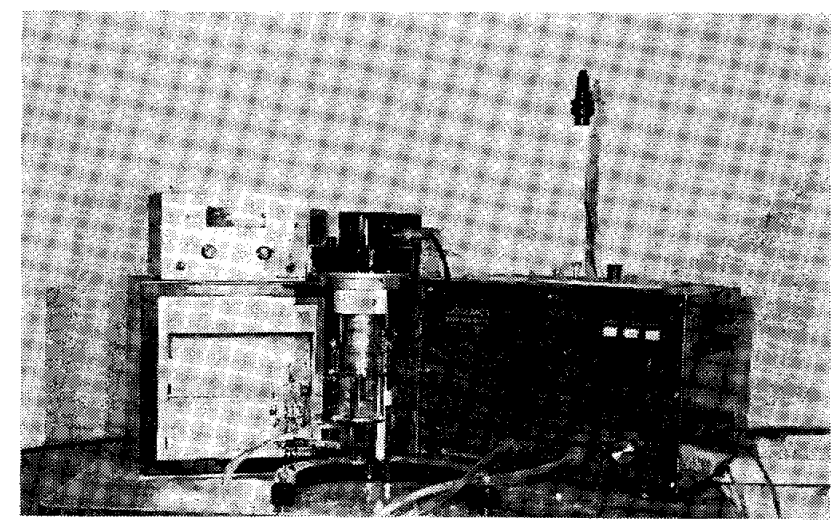

Fig. 1 Apparatus used for measurement of viscosity.

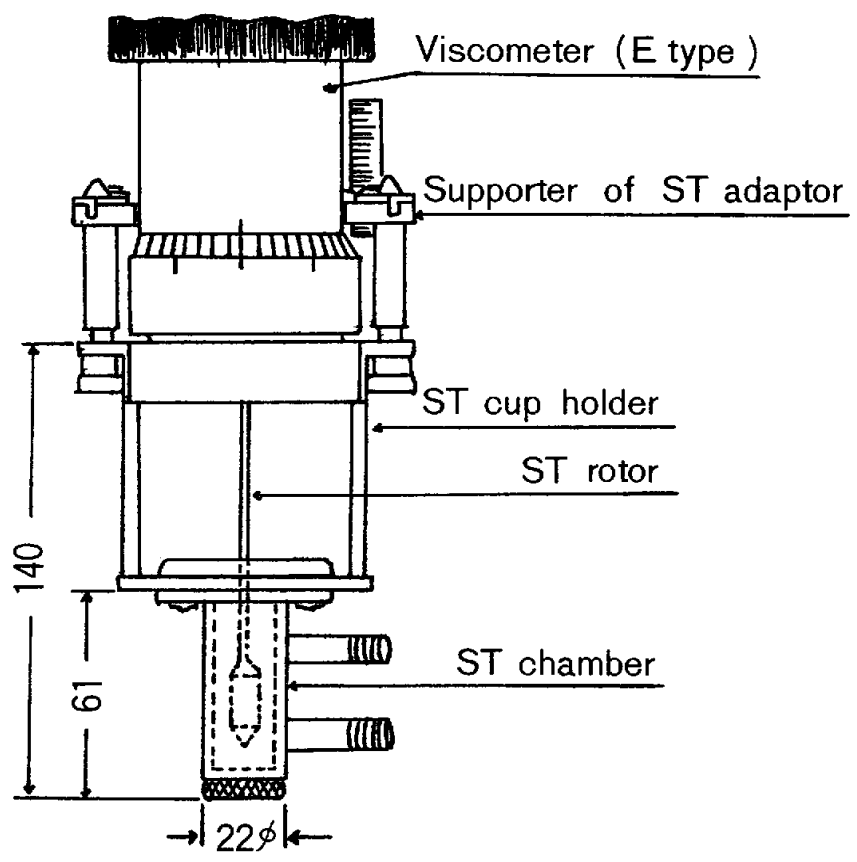

Fig. 2 Line diagram of ST adaptor.

復元トルクとが互いに平衡状態になるまで続く、ての平 衡状態でのスプリングのねじれ角度を目盛板上で続み取 る.

指針の示す目盛数はデジタル式表示器に表示される. サンプルカップ（ST型）の外周にはジャットが付与 され (Fig. 2), 外部循環式恒温槽汃引熱媒を循環させ てサンプルカップ中の温度を一定に保つょうにしてあ る. その温度は銅ーコンスタンタン熱電対を用いて温度 記録計に直接記録する仕組になっている。

\section{2）奏験方法}

すべての材料について，メ一力指示の粉液比で練和し た基準試料と，てれより液に詨する粉末の量を多くした 試料と少なくした試料の 3 種類を作製して測定に供し

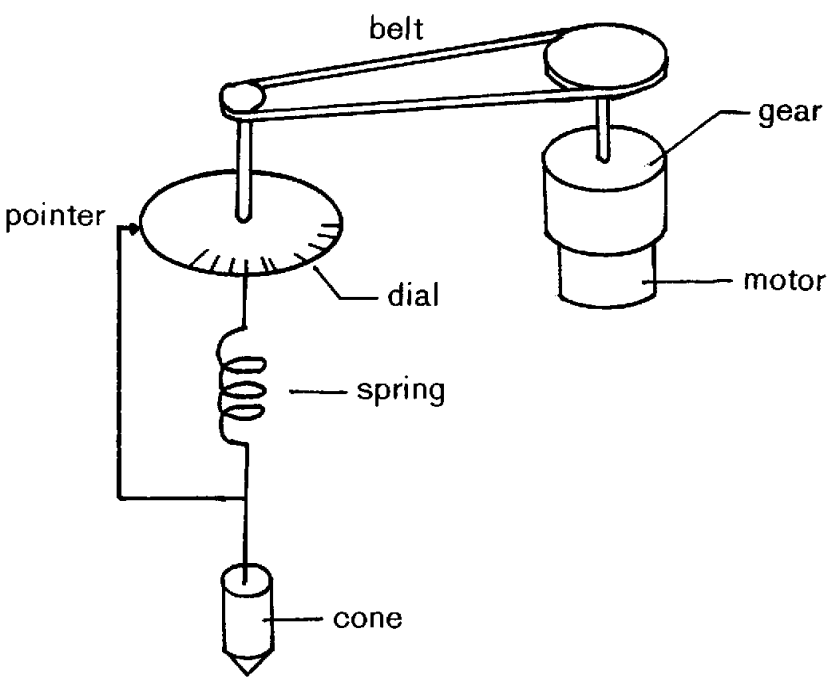

Fig. 3 Diagramatic representation of viscometer .

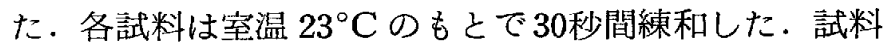
を注入するサンプルカップの温度，すなわち試料雾囲気 温度は $23^{\circ} \mathrm{C}$ と $37^{\circ} \mathrm{C}$ の 通りとした。

練和した試料をプラスチック製のシリンジを用いて $2 \mathrm{ml}$ 採取し, 可及的短時間内にサンプルカップに注入 し, 粘度計本体にセットした. 全ての試料は練和開始後 1 分30秒から測定した.

\section{3) 粘度の決定}

本実験に使用した粘度計はコーン・プレート式回転粘 度計のコーン・プレート部を Fig. 2 に示すST 型ロー 夕に変えたもので, そのときの粘度（ク）は次式で示さ れる42)。

$$
\eta=\mathrm{K} \cdot \frac{\theta}{\mathrm{N}} \quad(\mathbf{c p})
$$

\section{ただし K は計器常数 \\ $\theta$ は目盛読取值}

Nはロータの回転数

である.本実験においては回転数を $0.5 \mathrm{r} \cdot \mathrm{p} \cdot \mathrm{m}$.一定と したため，(1)式の $\frac{\mathrm{K}}{\mathrm{N}}$-は $1.86 \times 10^{5}$ となり

$$
\eta=1.86 \times 10^{5} \theta \quad \text { (cp) }
$$

で表わされる.

\section{奏験 2 (弾性率の測定)}

1) 测定装置

笑験に使用した測定器は英国規格（BS 5199：1975） に示されているコンポシットレシンン用の測定器を印象材 用に改良した Wilson一井上式レオメーターである. 43ー46) 装置ならびにその機構については Fig.4，5 亿 


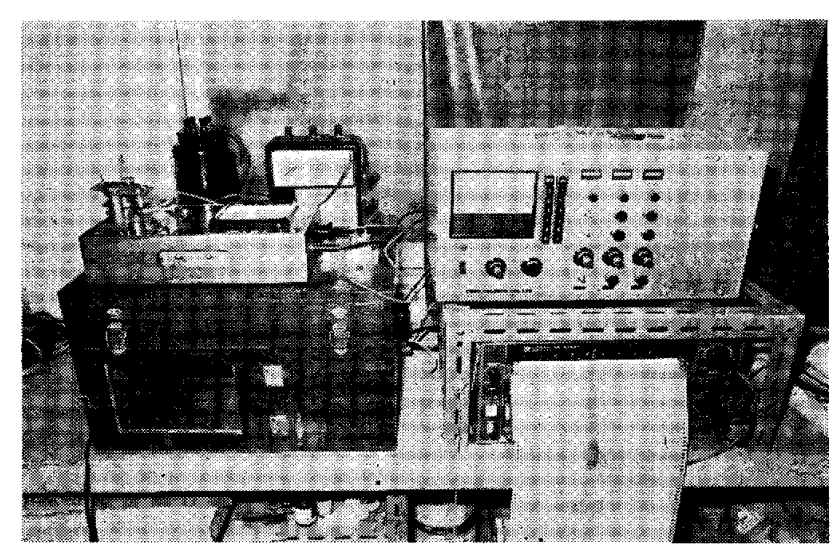

Fig. 4 Apparatus used for measurement of torsional shear modulus.

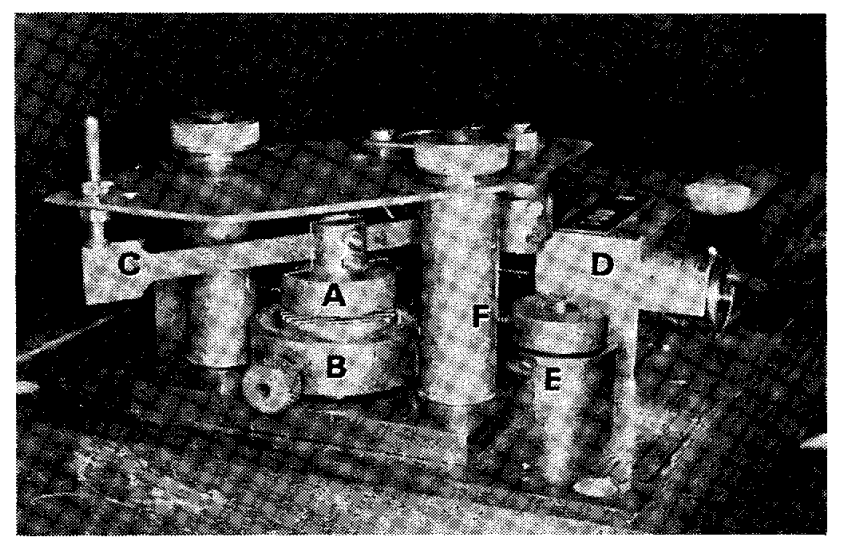

Fig. 5 Modified oscilating rheometer.

示す，装置の主要部分は 2 枚の試料保持用金属プレー 卜 $(\mathrm{A}, \mathrm{B})$ ， ストレンゲージを接着した固定ビーム (C), 差動トランス (D), 駆動用モータ (E), 振動 伝達用アーム扰びバネ（F）より構成されている。試 料を 2 枚の金属プレート閒におき，毎分12回のねじり振 動を与える。乙のねじり振動は駆動用モータから振動伝 達用バネならびにアームに及び，下部金属プレートを通 って試料に㑂達される。そのねじり振動によって試料中 に生じた応力は上部金属プレートの固定ビーム上に接着 されたストレンゲージで電気信号に変換した後, レコー ダで記録する，また試料に与えるひずみの大きさは，振 動伝達用アームにとりつけた差動卜ランスで電気信号に 変換した後，応力とともに同時記録する。

印象材の硬化にともなって試料はひずみにくくなり， 駆動用モータによって与えられるひずみ（一定）はモー タと下部金属プレート間にセットした振動伝達用バネに より補われる。従って硬化反态が主ば完了したと思われ る時期では，闭者のひずみはともに一定值を示すように なる。
なお測定に際しては試料の雾囲気を一定に保つために レオメータを恒温空気浴槽にセットした。

\section{2) 実験方法}

5 種類の機能的印象材についてメ一力指示の粉液比 (Table 1) で室温 $23^{\circ} \mathrm{C}$ のもど 30 秒間練和して測定 に供した，練和後直ちに試料保持用金属プレート（A， B）間に試料を置き， 1 分間そのままの状態で放置した 後, 測定を開始した.

試料䨋囲気温度は $23^{\circ} \mathrm{C}, 37^{\circ} \mathrm{C} の 2$ 通りとした。

3）弾性率の決定

2 枚の試料保持用金属プレート間に置いた試料は下部 金属プレートによりねじられる.その状態を Fig.6 に 示す.
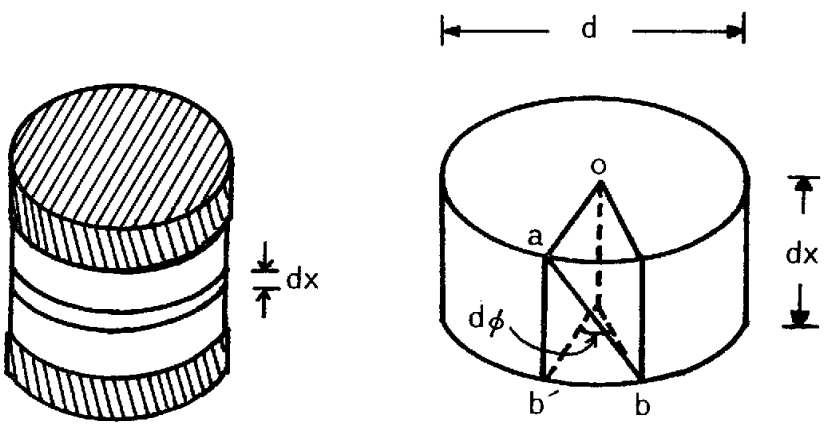

Fig. 6 Model of specimen in torsion.

この図から明らかなようにねじりモーメントによる試 料のひずみとは

$$
r=\frac{\mathrm{bb}^{\prime}}{\mathrm{ab}^{\prime}}=\frac{1}{2}-\frac{\mathrm{d} \varphi}{\mathrm{d} x} \mathrm{~d}=-\frac{1}{2} \theta \mathrm{d}
$$

で表わされる。ここで $\theta$ は愿さ $\mathrm{d} x$ だけ隔った 2 面の相 娰水じ量 $\frac{\mathrm{d} \varphi}{\mathrm{d} x}$ を示す.

またねじれによって生ずるずり応力てはフックの法則 により次式で導かれる。

$$
\tau=\mathrm{G} r=\frac{1}{2} \mathrm{G} \theta \mathrm{d}
$$

直径 $\mathrm{d}$ の円柱状試料にかかるトルク

$$
\mathrm{M}=\mathrm{G} \theta \mathrm{Ip}
$$

で表わされる．ここでIp は断面 2 次モモーメントで $\frac{\pi \mathrm{d}^{4}}{32}$-で示される.よって(3)式は

$$
\mathrm{M}=\frac{\mathrm{G} \theta \pi \mathrm{d}^{4}}{32}
$$

と畫き換えられ

$$
\theta=\frac{32 \mathrm{M}}{\mathrm{G} \pi \mathrm{d}^{4}}
$$

となる。(2)，(4) 式から試料中に生ずるずり応力 $\tau \max$ は 


$$
\tau_{\max }=\frac{1}{2} \mathrm{G} \theta \mathrm{d}=\frac{16 \mathrm{M}}{\pi \mathrm{d}^{3}}
$$

で求めるととができる。

$$
\mathrm{G}=\frac{\tau \max }{\gamma}
$$

であるから，試料のずり弾性率 $\mathrm{G} は(1) ，(5)$ 式から求めら れる、47-49!

奏験 3 (顕微鏡による観察)

1) 顕微鏡

実験に使用した顕微鏡は生物顕微鏡 L型（ニコン社製） に AFM 型写真撮影装置を装着したものである.

2）笑験方法

室温 $23^{\circ} \mathrm{C}$ のとで HS, TP の粉末を少量スライドガ ラス上にとり，練和液を㵜下した。

液を滴下した後 $2,3 ， 5 ， 10 ， 15$ 分の各時点におけ る顕微鏡像を $10 \times 10$ の倍率で観察した。

実験 4 (水分，エタノールの検出）

\section{1）測定装置}

実験に使用した装置はガスクロマトグラフ GC- $5 \mathrm{~A}$ 型（島津製作社製）である。その装置ならびに原理図に ついて Fig. 7 および Fig. 8 に示す. 本装置は主と してキァリアガス流量制御部, 試料導入部, カラム, 力 ラム流路系, 恒温槽, 検出器および記録計により構成さ れる(Fig.8). 本実験では, 検出器に熱伝導度検出器 (TCD) 老使用した50)。

\section{2）尖験方法}

試料作製にあたってはすべての材料をメ一カ指示の粉 液比（Table 1) で練和した，室温 $23^{\circ} \mathrm{C}$ のもとで30秒 間練和したのちサンプルビン $(50 \mathrm{~mm} \times 24 \mathrm{~mm} \phi)$ に 1 $\mathrm{m} \ell$ をとり, 練和開始力ら 5 分のちに $37^{\circ} \mathrm{C}$ の蒸留水 5 $\mathrm{m} \ell$ を加えた。密閉した状態で更に全体を $37^{\circ} \mathrm{C}$ 恒温槽

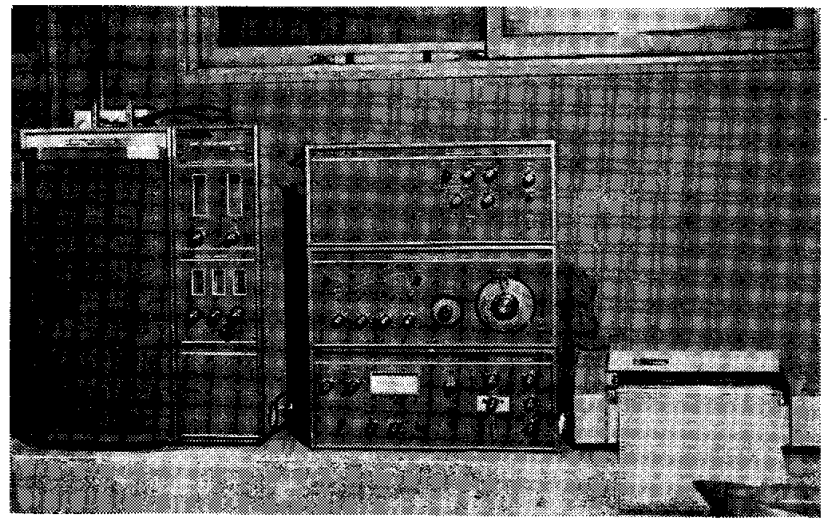

Fig. 7 Apparatus used for gas chromatography.

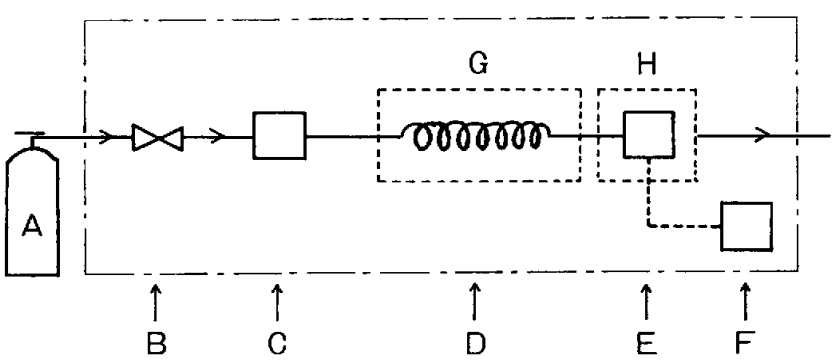

Fig. 8 Diagramatic representation of gas chromatography.

A : bomb $\left(\mathrm{N}_{2}\right)$ B : control part of carrier gas $\mathrm{C}:$ injection part of sample D: column E : detecter $F$ : recoder $G$ : air bath for column $\mathrm{H}$ : air bath for detecter

中に保存した．各試料の浸漬時間は 10 分, 30 分, 1 時間, 5 時間. 24 時間, 72 時間, とした。

所定の時間浸漬後サンプルビンの中の各試料上の水分 をとり除き，水のかわりにアセトン $90 \%$ とメタノール10 $\%$ を混和した溶媒 $10 \mathrm{~m} \ell$ を加え，密封した状態で24時間 放置した。これにより完全に溶解した試料 $2 \mu \ell$ をイ クロシリンジを用いて採取し，ガスクロマトグラフの試 料導入部に注入して測定に供した。

本実験におけるガスクロマトグラフの測定は次の分析 条件で行った。
カラム：ポラパック $\mathrm{N}$
$80,100 \quad 3 \mathrm{~mm} \phi \times 3 \mathrm{~m}$
カラム温度 : $140^{\circ} \mathrm{C}$
気化室温度 : $140^{\circ} \mathrm{C}$
検出器温度 : $150^{\circ} \mathrm{C}$
キャリアガス: $\mathrm{N}_{2} 60 \mathrm{~m} \ell / \mathrm{min}$
検出器：TCD

$$
\begin{aligned}
& \text { レンジ： } 2 \mathrm{mV} \\
& \text { チャートスピード : } 5 \mathrm{~mm} / \mathrm{min}
\end{aligned}
$$

3）相対重量感度の決定および定量分析の方法

使用する充てん剂の種類によって試料中の各成分の相 対重量感度が異なるため，記録されたチャートから定量 分析を行う場合には，あらかじめ成分相対重量感度の補 正（補正係数の決定）を行う必要がある。

いま Fig. 9ーIに示すように $\mathrm{A}_{1} \sim \mathrm{A}_{4}$ の成分を全て $1 \mathrm{~g}$ 当量ずつ混和した試料をクロマトグラフで分析した とすると, $\mathrm{A}_{1} \sim \mathrm{A}_{4}$ のピーク面積は半值幅法により， それぞれ $\mathrm{W}_{1}{ }^{\prime} \mathrm{h}_{1}{ }^{\prime} \sim \mathrm{W}_{4}{ }^{\prime} \mathrm{h}_{4}{ }^{\prime}$ と表される.とこで $\mathrm{A}_{3}$ の ピーク面積に対する $\mathrm{A}_{1} \sim \mathrm{A}_{4}$ のピーク面積の比をとると 
I

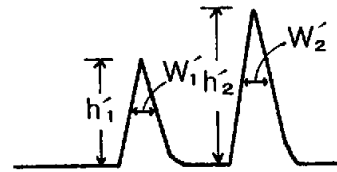

$A_{1}$
$\mathrm{A}_{3}$

$\mathrm{A}_{4}$

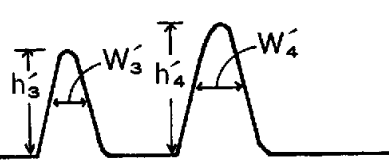

II

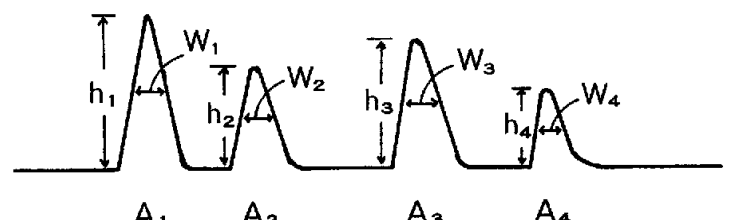

Fig.9 I : Diagramatic representation of gas chromatogram chart obtained by four solvents (which contain every 1 gram equivalent).

II : Diagramatic representation of gas chromatogram chart for quantiative analysis.

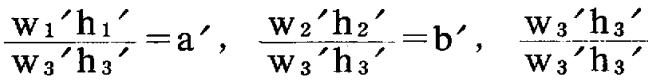

$$
\begin{aligned}
& =1, \frac{\mathrm{w}_{4}^{\prime} \mathrm{h}_{4}^{\prime}}{\mathrm{w}_{3}^{\prime} \mathrm{h}_{3}^{\prime}}=\mathrm{d}^{\prime}
\end{aligned}
$$

と表すことができる。ここで得られた $a^{\prime} ， b^{\prime} ， 1, d^{\prime}$ の值を相対重量感度といい，補正係数として定量分析に 使用した。

たとえば実際の試料を測定した時に $\mathrm{A}_{1} \sim \mathrm{A}_{4}$ の成分は Fig. 9-II に示すように表されたとすると， $\mathrm{A}_{1} \sim \mathrm{A}_{4}$ のピーク面積は $\mathrm{w}_{1} \mathrm{~h}_{1} \sim \mathrm{W}_{4} \mathrm{~h}_{4}$ となり， $\mathrm{A}_{1}$ の場合は

$$
\begin{gathered}
\frac{\frac{\mathrm{w}_{1} \mathrm{~h}_{1}}{\mathrm{a}^{\prime}}}{\frac{\mathrm{w}_{1} \mathrm{~h}_{1}}{\mathrm{a}^{\prime}}+\frac{\mathrm{w}_{2} \mathrm{~h}_{2}}{\mathrm{~b}^{\prime}}+\frac{\mathrm{w}_{3} \mathrm{~h}_{3}}{1}+\frac{\mathrm{w}_{4} \mathrm{~h}_{4}}{\mathrm{~d}^{\prime}}} \\
\left.\times 100=\mathrm{A}_{1} \text { ピーク }^{\circ} \%\right)
\end{gathered}
$$

と求めることができる．以下 $\mathrm{A}_{2} \sim \mathrm{A}_{4}$ についても同様に 定量分析される.
本実験においてはあらかじめ水，メタノール，エタノ 一ル，アセトンを $1 \mathrm{~g}$ 当量ずつ混和した試料を測定し， メタノールに対する相対重量感度を求め, 定量分析の際 の補正係数として使用した。その記録したチャートを Fig.10 亿示す。 このチャートから得られた各成分のピ 一ク面積抢よび相対重量感度（補正係数）については Table 2 に示す.

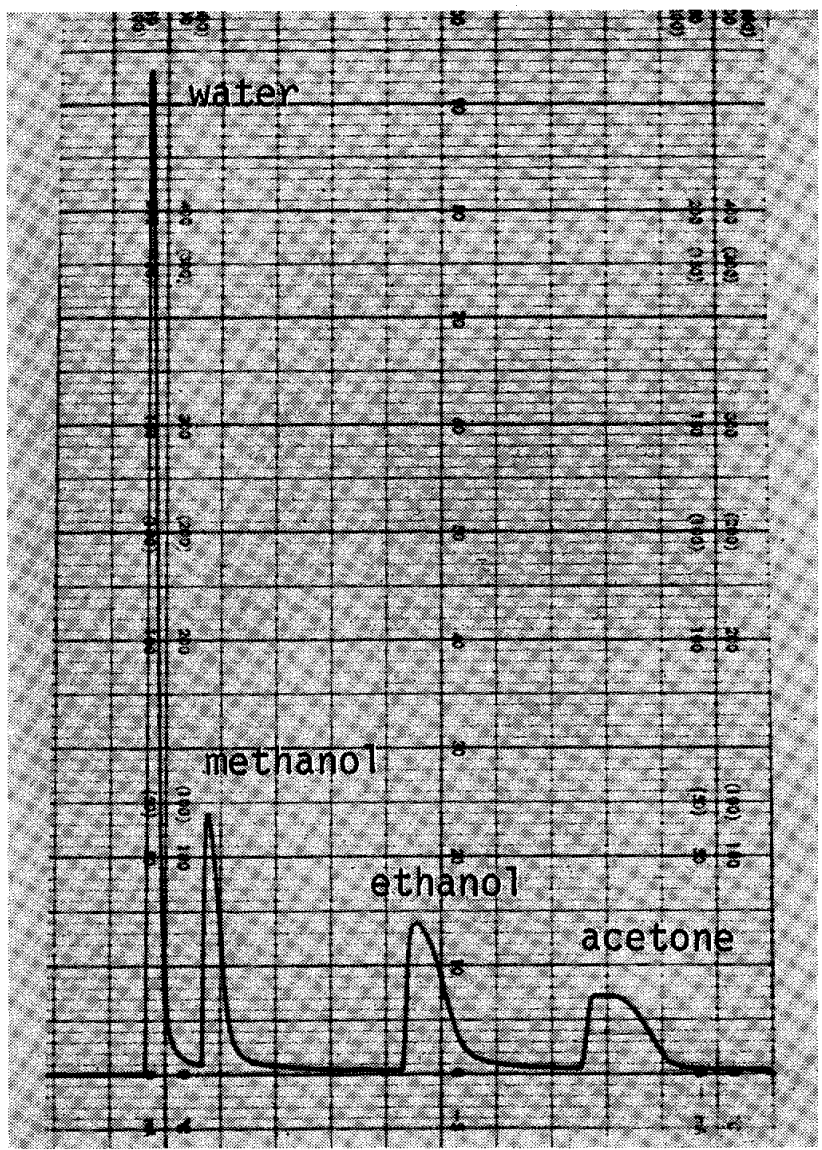

Fig.10 Gas chromatogram chart obtained by four solvents (which contain every 1 gram equivalent).

Table 2 Relative weight sensitivity of water, ethanol and acetone against methanol.

\begin{tabular}{c|cccc}
\hline \hline & Water & Methanol & Ethanol & Acetone \\
\hline $\begin{array}{c}\text { Peak area }\left(\mathrm{cm}^{2}\right) \\
\begin{array}{c}\text { Relative weight } \\
\text { sensitivity }\end{array}\end{array}$ & 3.49 & 1.61 & 2.11 & 1.66 \\
(calibrate factor) & 2.17 & 1.00 & 1.31 & 1.03 \\
\hline
\end{tabular}




\section{III 実 験 結 果}

1) 粘度測定

すべての材料をメーカ指示の粉液比で練和して測定し た時の練和開始からの粘度の変化を Fig.11 亿示す。乙

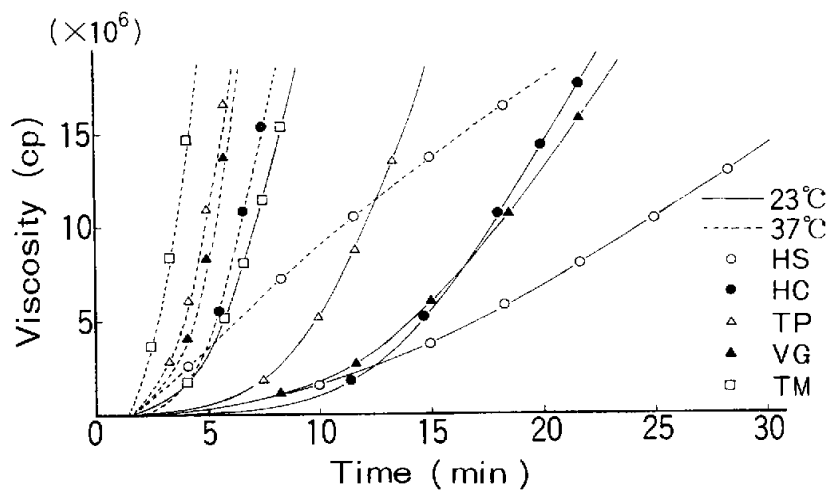

Fig.11. Variation of viscosity with time from start of mix for functional impression materials at $23^{\circ} \mathrm{C}$ and $37^{\circ} \mathrm{C}$.

の図によると $23^{\circ} \mathrm{C}$ 犂囲気で測定した試料（以下単に $23^{\circ} \mathrm{C}$ 試料と呼ぶ）は $37^{\circ} \mathrm{C}$ 舅用気で測定した試料（以 下単に $37^{\circ} \mathrm{C}$ 試料と呼ぶ) に比心，練和開始汃ら急激な 粘度上昇がみられるまでの時間が橆く, 最も短いもので 4 分, 長いものでは10分であった。各試料とも粘度がほ ぼ直線的な上昇を示すようになる時間（粘度值では $10^{7}$ cp）で比較すると， $\mathrm{TM}$ 試料 7.2分， $\mathrm{TP}$ 試料では 12.2 分, $\mathrm{HC}$ 試料では 17.7 分, $V G$ 試料では 18.2分, $H S$ 試 料では24.6分となり HS 試料が他の試料に比へてて最も長 い時間を要した。

$37^{\circ} \mathrm{C}$ 試料では測定開始と同時に著しい粘度变化がみ られ， $23^{\circ} \mathrm{C}$ 試料と同じく $10^{7} \mathrm{cp}$ 亿達する時間で比較す ると $\mathrm{TM}$ 試料が 3.5 分で最も短く, $\mathrm{TP}$ 試料では 4.9 分, $\mathrm{VG}$ 試料では 5.3 分, $\mathrm{HC}$ 試料6.5分, $\mathrm{HS}$ 試料 11 分の順に 展くなった。 HS 試料の粘度上昇の傾向は他の 4 試料と 異なり練和開始後約 12 分 $\left(1.1 \times 10^{7} \mathrm{cp}\right)$ 加ら粘度上昇率 $\left(\begin{array}{c}\mathrm{d} \eta \\ \mathrm{dt}\end{array}\right)$ はやや小さくなる傾向を示した.

メ一カー指示の粉液比を基準に臨床で使用し得ると思 われる程度に粉液比を変えて練和した試料（Table 3) の粘度一時間曲線を Fig.12〜16 に示す．とれらのグラ フによると，いずれの試料もメ一力指示の粉液比のもの に比へて粉末を多くすると練和開始後の粘度上昇が早く 現われるとともに，その上昇率も大きくなり，粉末を少 なくするとその逆の傾向を示した。この粉液比の影響を

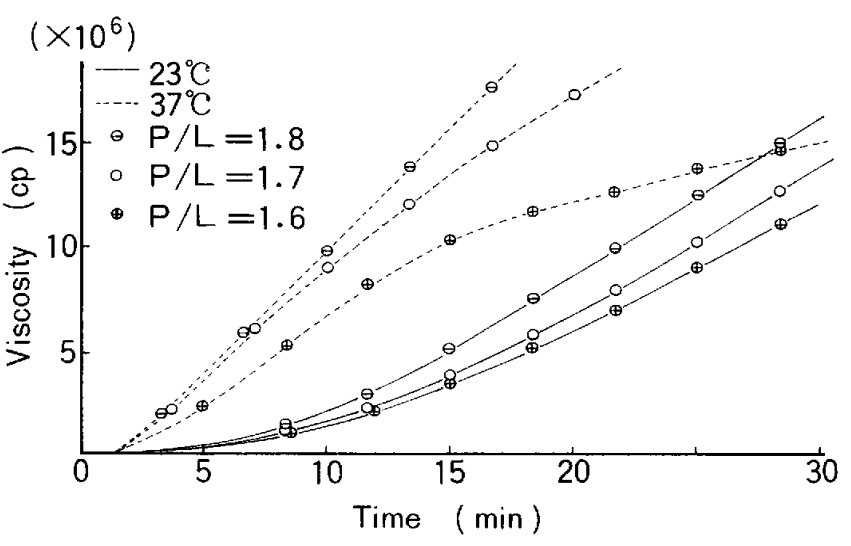

Fig.12 Variation of viscosity with time from start of mix for various $\mathrm{P} / \mathrm{L}$ ratio of $\mathrm{HS}$ at $23^{\circ} \mathrm{C}$ and $37^{\circ} \mathrm{C}$.

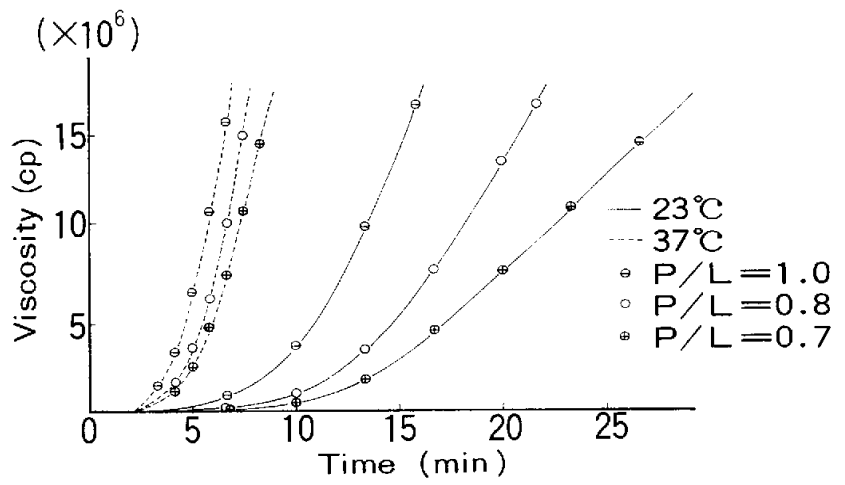

Fig.13 Variation of viscosity with time from start of mix for various $\mathrm{P} / \mathrm{L}$ ratio of $\mathrm{HC}$ at $23^{\circ} \mathrm{C}$ and $37^{\circ} \mathrm{C}$.

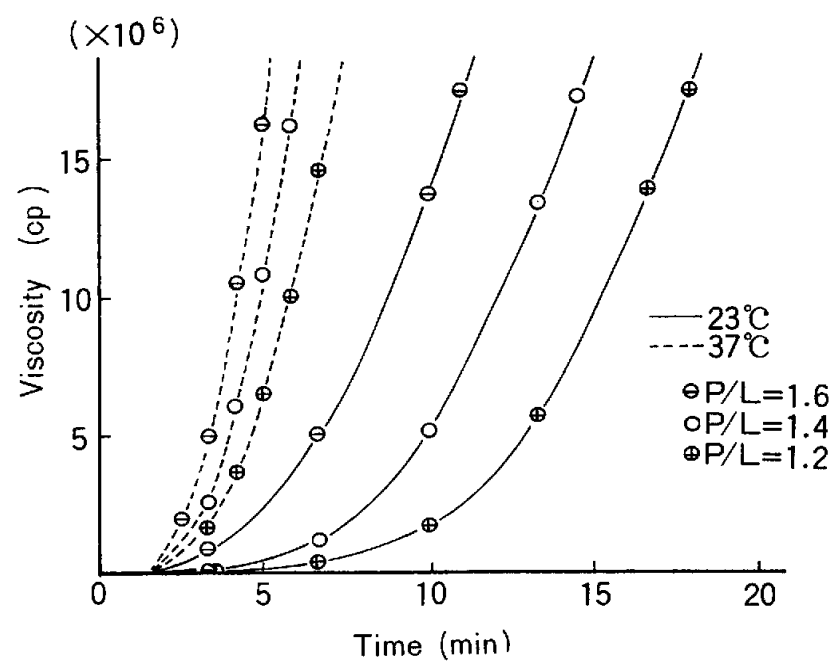

Fig.14 Variation of viscosity with time from start of mix for various $\mathrm{P} / \mathrm{L}$ ratio of $\mathrm{TP}$ at $23^{\circ} \mathrm{C}$ and $37^{\circ} \mathrm{C}$. 


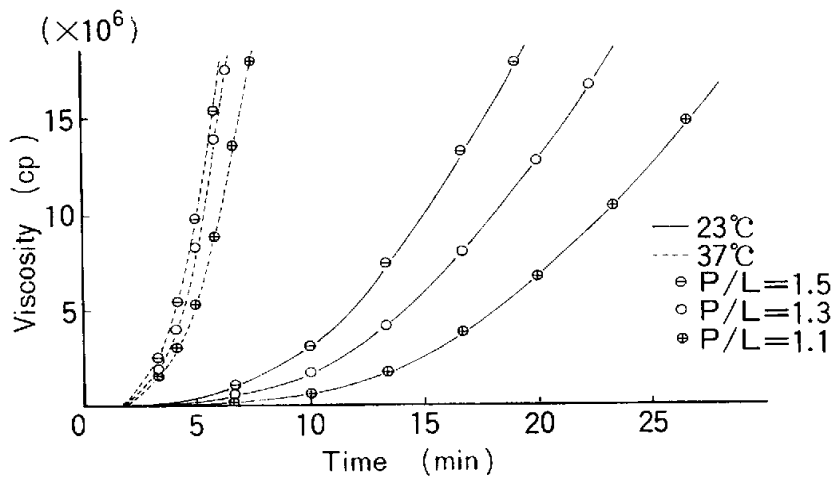

Fig.15 Variation of viscosity with time from start of mix for various $P / L$ ratio of $V G$ at $23^{\circ} \mathrm{C}$ and $37^{\circ} \mathrm{C}$.

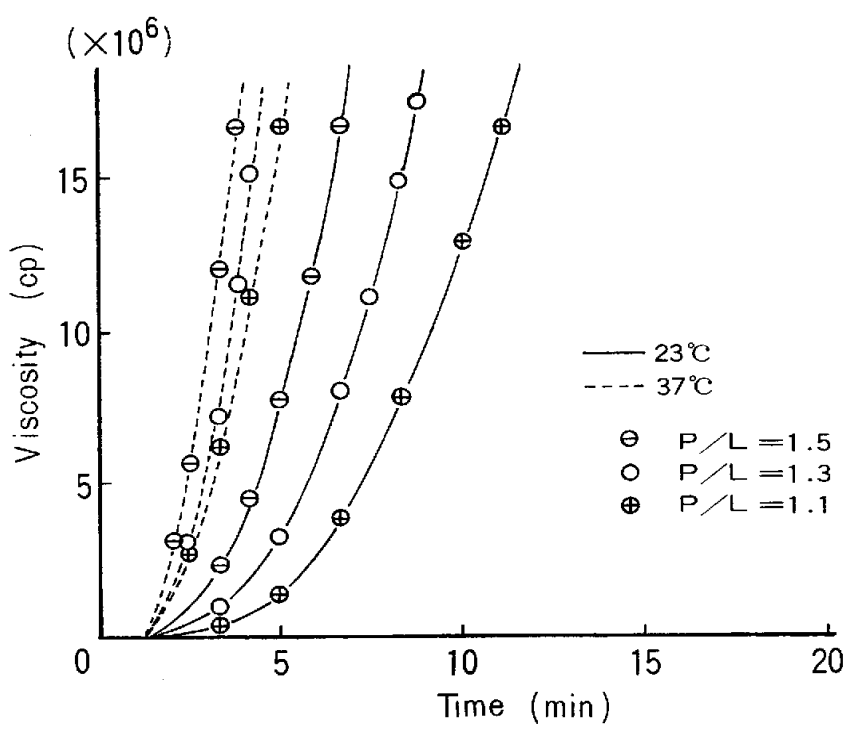

Fig.16 Variation of viscosity with time from start of mix for various $\mathrm{P} / \mathrm{L}$ ratio of $\mathrm{TM}$ at $23 . \mathrm{C}$ and $37^{\circ} \mathrm{C}$.

比較検討するために一定粘度 $10^{7} \mathrm{cp}$ に達する時間をと り，その時間と粉液比の関係を Table 3 および Fig.17 に示す. Fig.17 では横軸の中央がメーカー指示の粉液 比 $(\mathrm{P} / \mathrm{L})$ を示し，右方が粉末を多くした場合で左方が粉 末を少なくした場合を示す。てれによると HS 試料では $23^{\circ} \mathrm{C}$ 試料， $37 \mathrm{C}^{\circ}$ 試料ともに粉液比によって粘度が $10^{7} \mathrm{cp}$ に達するまでの時間に差異が認められた。これに対し他 の 4 試料では $23^{\circ} \mathrm{C}$ 試料の場合にはその差異が試められ るが， $37^{\circ} \mathrm{C}$ 試料の場合には大きな差異は認められなか った。

\section{2) 弾性率の測定}

$23^{\circ} \mathrm{C}$ 試料の場合の練和開始から 15 分までのねじり振 動によるずり弾性率（以下単に弾性率と呼ぶ）の変化を
Table 3 Time when the viscosity of mixture of various functional impression materials come to $10^{7} \mathrm{cp}$.

\begin{tabular}{c|c|cc}
\hline \multirow{2}{*}{ Material } & \multirow{2}{*}{$\mathrm{P} / \mathrm{L}$} & \multicolumn{2}{|c}{ Time (min) } \\
\cline { 3 - 4 } & & $23^{\circ} \mathrm{C}$ & $37^{\circ} \mathrm{C}$ \\
\hline \multirow{3}{*}{$\mathrm{HS}$} & 1.6 & 26.62 & 14.25 \\
& 1.7 & 24.55 & 11.00 \\
& 1.8 & 21.65 & 10.17 \\
\hline \multirow{3}{*}{$\mathrm{HC}$} & 0.7 & 21.70 & 7.10 \\
& 0.8 & 17.65 & 6.50 \\
& 1.0 & 13.10 & 5.55 \\
\hline \multirow{3}{*}{ TP } & 1.2 & 15.18 & 5.87 \\
& 1.4 & 12.10 & 4.90 \\
& 1.6 & 8.62 & 4.18 \\
\hline \multirow{3}{*}{ VG } & 1.1 & 23.00 & 6.00 \\
& 1.3 & 18.13 & 5.28 \\
& 1.4 & 14.95 & 5.03 \\
\hline \multirow{2}{*}{ TM } & 1.1 & 9.10 & 3.95 \\
& 1.3 & 7.15 & 3.55 \\
\hline
\end{tabular}

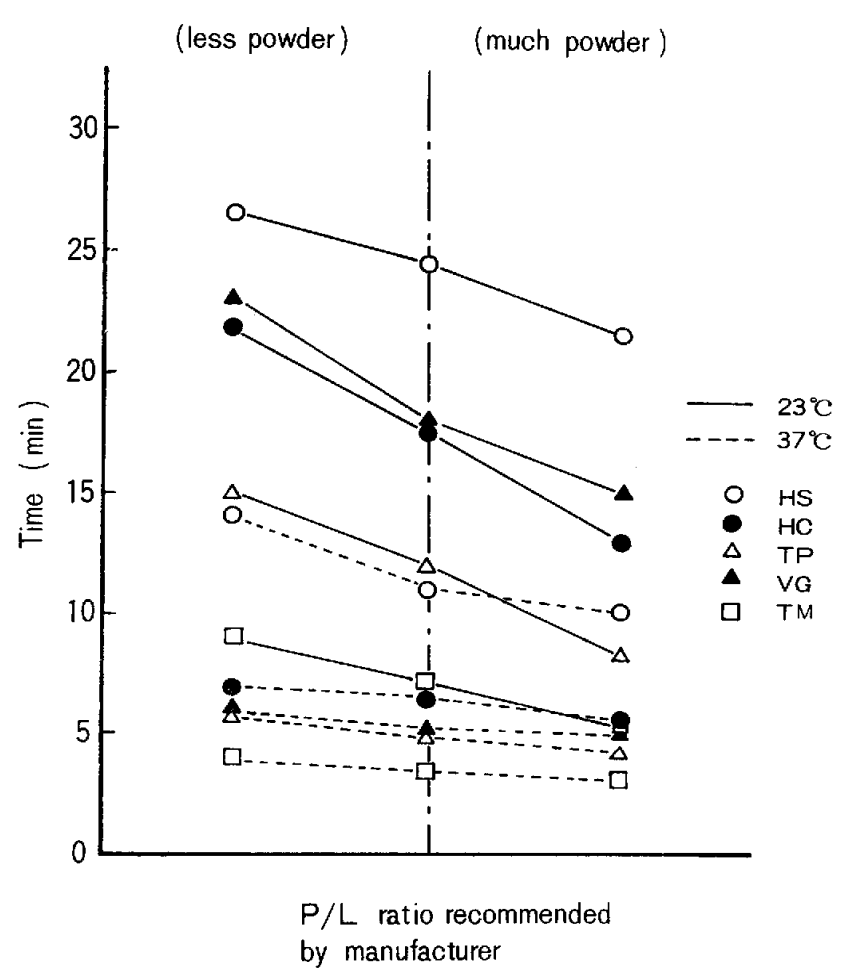

Fig.17 Variation of time when the viscosity comes to $10^{7} \mathrm{cp}$ with powerliquid ratio $(\mathrm{P} / \mathrm{L})$ at $23^{\circ} \mathrm{C}$ and $37^{\circ} \mathrm{C}$. 
Table 4 および Fig.18に示す.乙れによると HC試料， $\mathrm{HS}$ 試料, $\mathrm{VG}$ 試料の弾性率の上界は TP試料, TM 試 に比べて小さく, 練和開始から15分後の弾性率はそれぞ れ $9.29 \times 10^{4}, 6.35 \times 10^{4}, 4.5 \times 10^{4} \mathrm{dyne} / \mathrm{cm}^{2}$ となっ た。

TP試料およびTM 試料では測定開始直後から弾性率 の上昇を示し, 練和開始加ら 3 分のちにその上昇は一段 と著しくなった。特に TP試料ではその後ほぼ直線的に

Table 4 Torsional shear modulus of mixture of various functional impression materials at $23^{\circ} \mathrm{C}$.

\begin{tabular}{c|ccccc}
\hline \multirow{2}{*}{$\begin{array}{c}\text { Time } \\
\text { min }\end{array}$} & \multicolumn{5}{|c}{ Torsional shear modulus } \\
$\left(\times 10^{4}\right.$ & HS $\left.\mathrm{dy} / \mathrm{cm}^{2}\right)$ & \\
\hline 2 & HC & TP & VG & TM \\
\hline 3 & 0.08 & 0.03 & 0.32 & 0.02 & 0.16 \\
4 & 0.18 & 0.13 & 1.42 & 0.05 & 0.92 \\
5 & 0.32 & 0.36 & 3.52 & 0.12 & 2.43 \\
6 & 0.52 & 0.78 & 6.00 & 0.22 & 4.13 \\
7 & 0.76 & 1.36 & 8.86 & 0.37 & 5.83 \\
8 & 1.19 & 2.10 & 11.6 & 0.59 & 7.38 \\
9 & 1.67 & 2.91 & 14.0 & 0.86 & 8.49 \\
10 & 2.22 & 3.81 & 16.9 & 1.23 & 9.75 \\
11 & 2.86 & 4.68 & 19.6 & 1.66 & 10.9 \\
12 & 3.55 & 5.61 & 21.6 & 2.13 & 11.7 \\
13 & 4.23 & 6.55 & 24.1 & 2.63 & 12.3 \\
14 & 4.93 & 7.43 & 26.1 & 3.23 & 13.0 \\
15 & 5.67 & 8.26 & 28.2 & 3.82 & 13.4 \\
& 6.35 & 9.29 & 30.5 & 4.50 & 14.0 \\
\hline
\end{tabular}

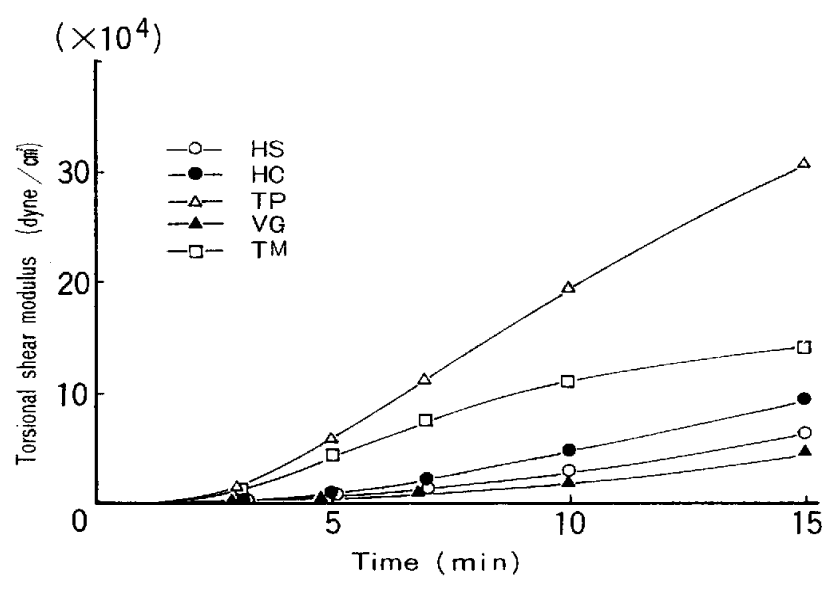

Fig.18 Variation of torsional shear modulus with time from start of mix for functional impression materials at $23^{\circ} \mathrm{C}$.
上昇し, 練和開始後 15 分の弾性率は同時点で最も低い值 を示したVG試料の弾性率に比べて約 7 倍の值 $(30.5 \times$ $\left.10^{4} \mathrm{dyne} / \mathrm{cm}^{2}\right)$ となった。それに比して TM試料では 練和開始後約 7 分から上昇率は徐々に低下して緩やかな $S$ 状のカーブを示し，15分後の弾性率はVG試料に比心゙ て約 3 倍の值 $\left(14.0 \times 10^{4} \mathrm{dyne} / \mathrm{cm}^{2}\right)$ となった。

Fig. 19 は室温 $23^{\circ} \mathrm{C}$ のもど 30 秒間練和したのち, $37^{\circ} \mathrm{C}$ の恒温空気浴中にセットされているレオメータ上 に移して測定した弾性率一時間曲線である，その測定值 についてはTable 5 に示す。てれによると各試料とも測 定直後から曲線は急激な立ち上がりを示し, 弾性率の著 明な上昇が認められた。VG試料を除く他の試料では練 和開始後約 20 分までは著しく上昇するが，その後は緩や かなカーブを示し，約39分経過後はほぽ一定の弾性率を 示すようになった，その変化は TP試料が最も著しく. 最も変化の少なかった HS 試料に比べて，その弾性率

（Table 5）は10分後では3.3倍，60分後では 2.8 倍とな った.VG 試料は練和開始後約 8 分までは他の試料に比 べて最も低い弾性率を示したが，その後は急激に上昇し， 約12分後には TP 試料に次いで大きい弾性率を示すよう になった.しかも他の試料に比べて60分経過後もその弾 性率は増加する傾向を示した。練和開始後60分の弾性率 (Table 5 ) は TP試料が最も大きく，次いでVG試料， HC試料, TM試料, HS試料の順に小さい值を示した。

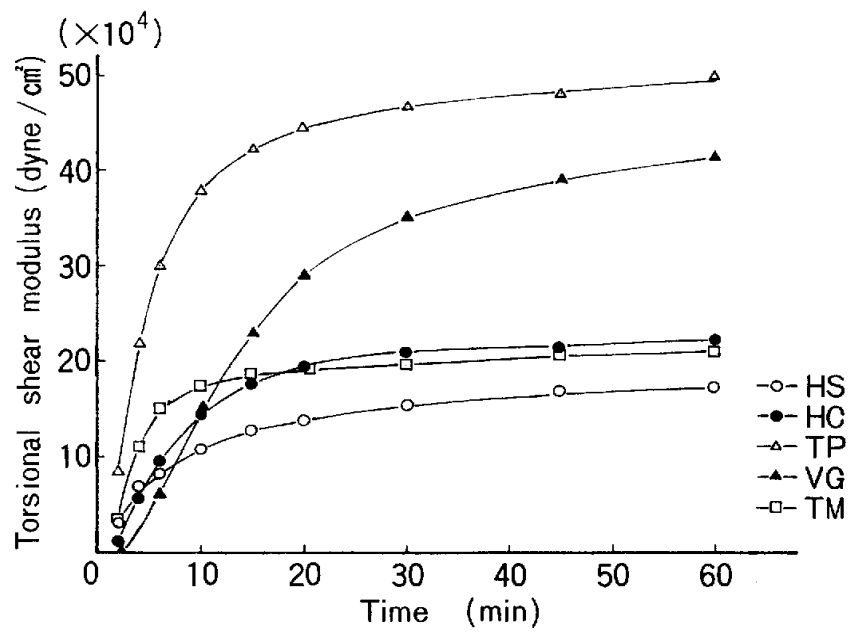

Fig.19 Variation of torsional shear modulus with time from start of mix for functional impression materials at $37^{\circ} \mathrm{C}$ after mixing at $23^{\circ} \mathrm{C}$ for $30 \mathrm{sec}$. 
Table 5 Torsional shear modulus of mixture of various functional impression materials at $37^{\circ} \mathrm{C}$.

\begin{tabular}{c|ccccc}
\hline \hline \multirow{2}{*}{$\begin{array}{c}\text { Time } \\
(\mathrm{min})\end{array}$} & \multicolumn{5}{|c}{ Torsional shear modulus } \\
$\left(\times 10^{4}\right.$ & dyne $\left./ \mathrm{cm}^{2}\right)$ \\
& HS & HC & TP & VG & TM \\
\hline 2 & 3.76 & 1.13 & 8.36 & 0.12 & 3.33 \\
3 & 6.13 & 3.35 & 15.2 & 0.86 & 8.24 \\
4 & 7.19 & 5.71 & 22.0 & 1.99 & 11.3 \\
5 & 8.63 & 7.80 & 26.7 & 4.02 & 13.5 \\
6 & 9.23 & 9.64 & 30.0 & 6.15 & 14.9 \\
7 & 9.80 & 11.2 & 32.6 & 8.49 & 15.8 \\
8 & 10.4 & 12.5 & 34.9 & 10.7 & 16.6 \\
9 & 10.9 & 13.9 & 36.4 & 13.0 & 17.3 \\
10 & 11.4 & 14.5 & 37.9 & 15.0 & 17.5 \\
15 & 12.8 & 17.8 & 42.1 & 23.3 & 18.5 \\
20 & 13.9 & 19.3 & 44.3 & 29.2 & 19.1 \\
30 & 15.6 & 21.0 & 46.4 & 35.3 & 19.7 \\
45 & 16.8 & 21.7 & 47.8 & 39.0 & 20.6 \\
60 & 17.5 & 22.4 & 49.7 & 41.5 & 21.0 \\
\hline
\end{tabular}

Fig.20はFig.19 亿示された各試料の弾性率一時間曲 線を図上微分して得られた練和後の時間に対する弾性率 の変化率 $\left\{\frac{\mathrm{d}\{\mathrm{G}(\mathrm{t})\}}{\mathrm{dt}}\right\}$ をプロットしたものである.てれ によると各試料の曲線のピークは此較的短時間に現わ れ, TM試料, HS武料では練和開始後 2 分, TP試料で は 3 分, $\mathrm{HC}$ 試料では 3.2 分, VG 試料では 6 分であっ た、そのピークは TP試料が最も幅の狭いシッープな形 を示し, TM, HS, HC, VG 試料の順に幅広くなった。 $23^{\circ} \mathrm{C}$ 試料の場合と $37^{\circ} \mathrm{C}$ 試料の場合とでは, 練和開始

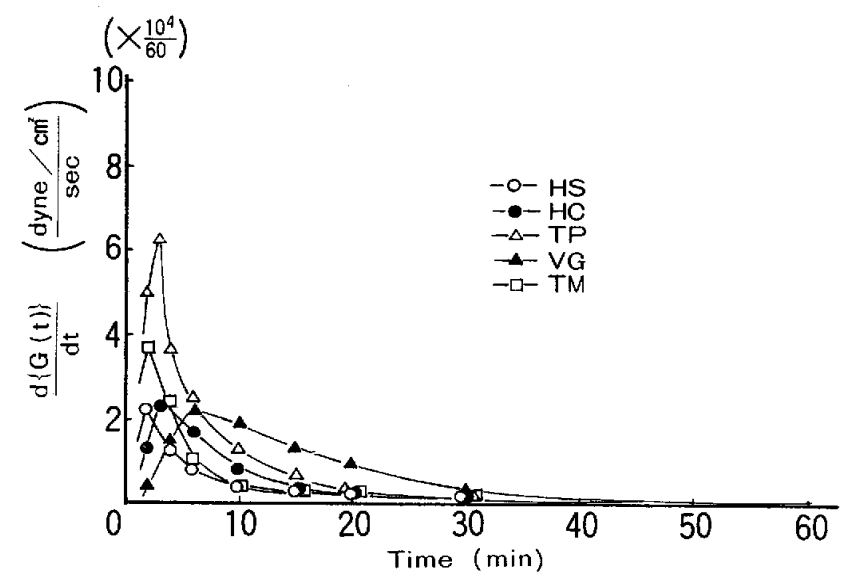

Fig.20 Variation of $\frac{d\{G(t)\}}{d t}$ with time after start of mix at $37^{\circ} \mathrm{C}$.
から同一時点における弾性率に著しい差がみられた。

Fig. 21 は練和開始後 15 分における弾性率を比較したも のである.いずれの試料においても $23^{\circ} \mathrm{C}$ 試料に比べて $37^{\circ} \mathrm{C}$ 試料の方が高い弾性率を示し, VG 試料では特に 著明な差がみられた。

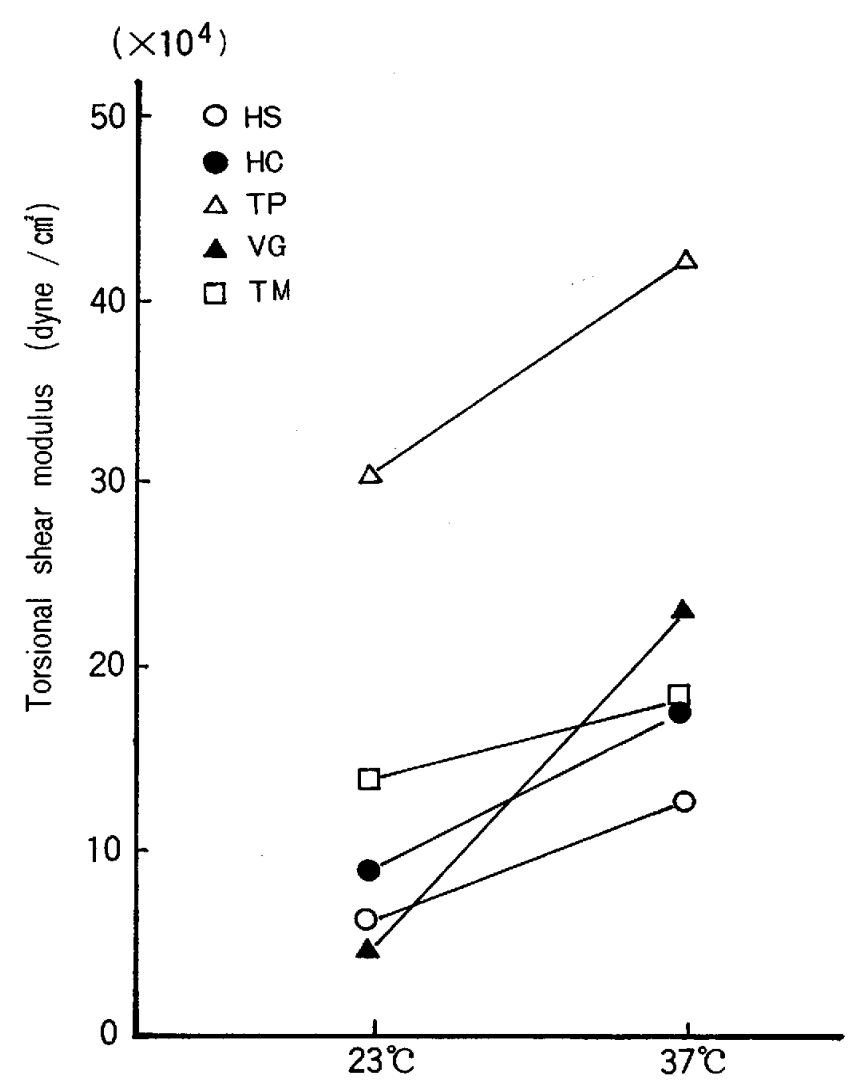

Fig.21 Variation of torsional shear modulus with temperature at $15 \mathrm{~min}$ from start of mix.

\section{3）顕微鏡による観察}

粘度および弾性率の測定の結果, 最も著しい差を示し た TP 試料と HS 試料について顕微鏡による観祭を行っ た. Fig.22〜33 は粉末に十分な量の練和液を加えた時 の粉末粒子の形状の経時的変化を示したものである.

TP 試料の場合は比較的大きい粒子では液滴下直後よ り明らかな膨潤を示し, $1 \sim 2$ 分後には一部崩壤を始め, 15分にはほぼ完全に形状を消失して液中に溶解した。し かし比僌的小さい粒子では液滴下15分後にも形状の変化 は全くみられなかった。

HS 試料ではすべての粒子が液となじみ，膨潤してい く状態が観察された，その膨潤は液の滴下約 2 分後に, 液に接触した表風から起こり，次第に内部に移行してい くのが観察された. 約 5 分後には外層の可溶性部分と中 


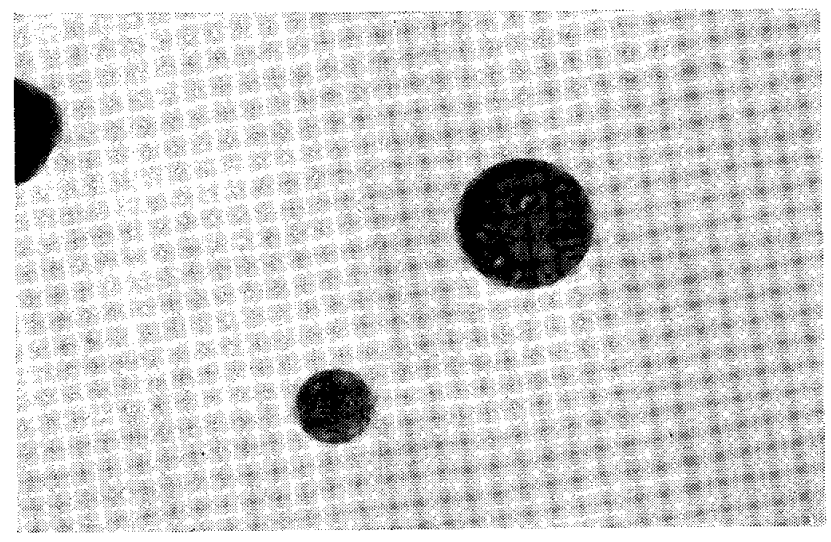

Fig.22 HS Powder.

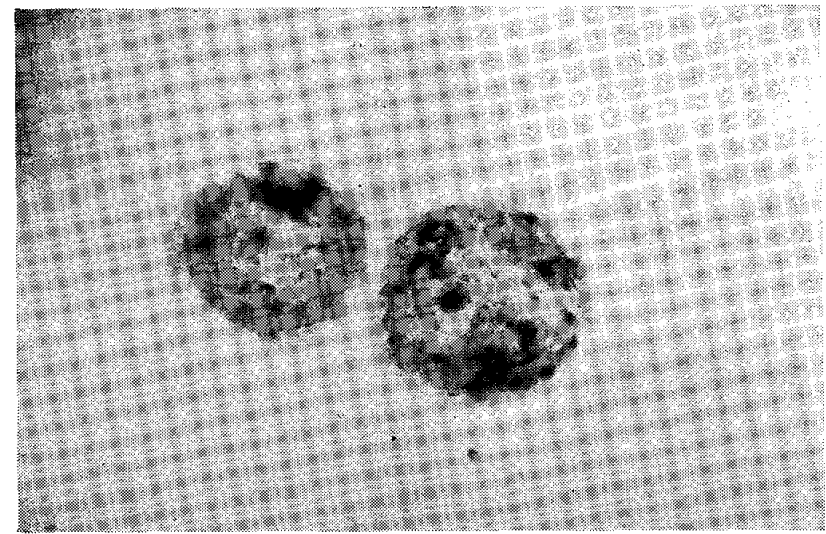

Fig.23 HS -2 minutes.

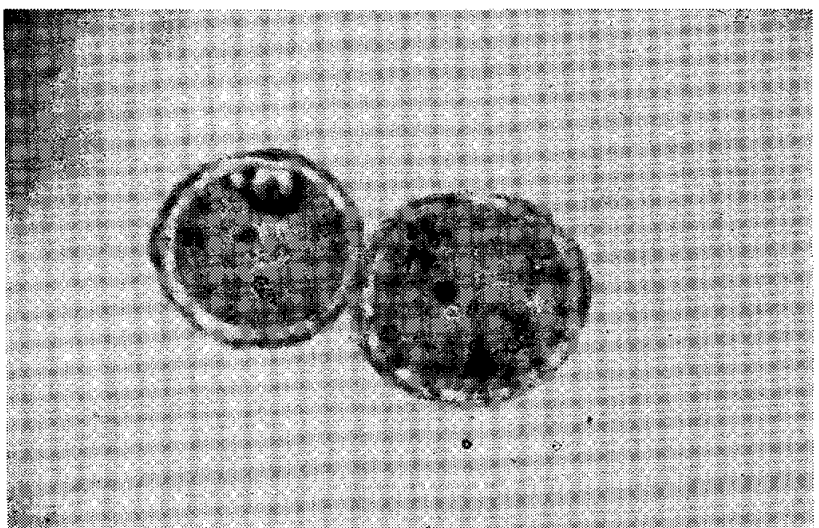

Fig.24 HS -3 minutes.

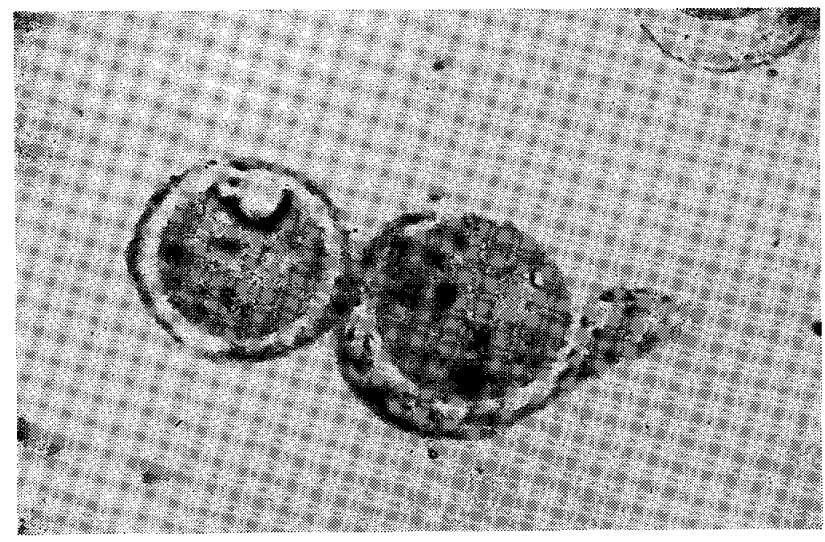

Fig.25 HS -5 minutes.

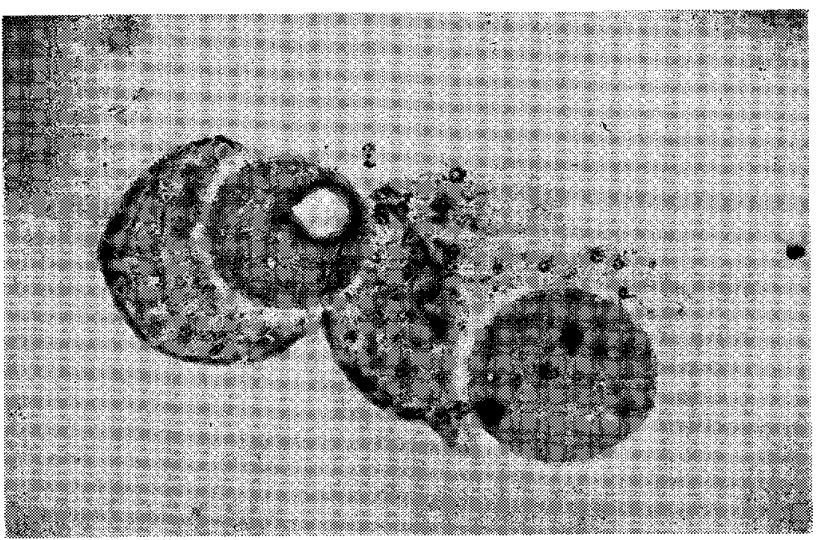

Fig.26 HS-10 minutes.

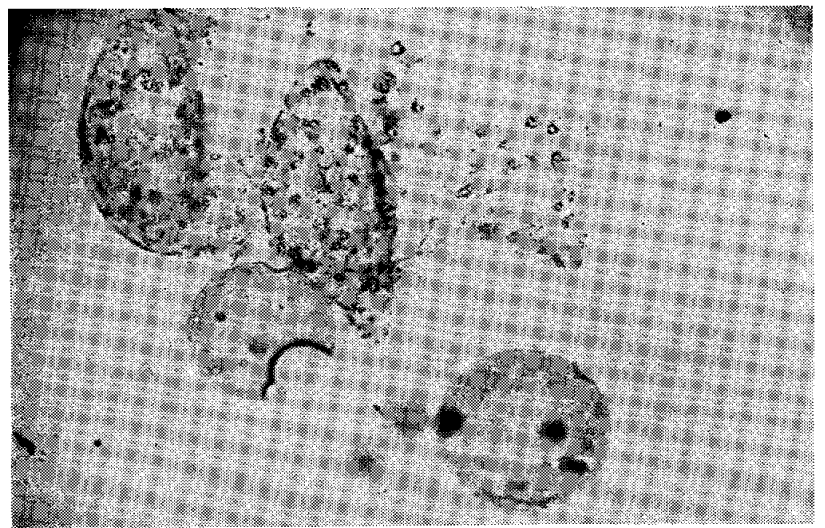

Fig.27 HS-15 minutes. 


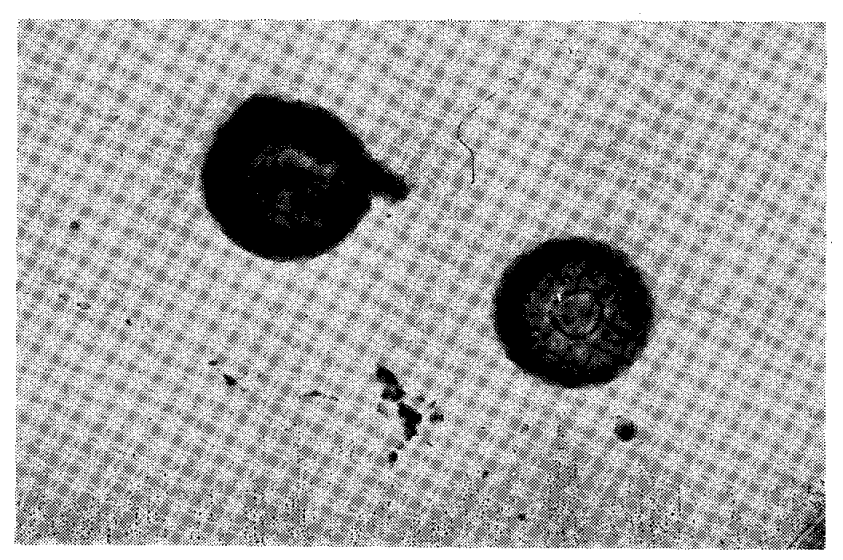

Fig.28 TP Powder.

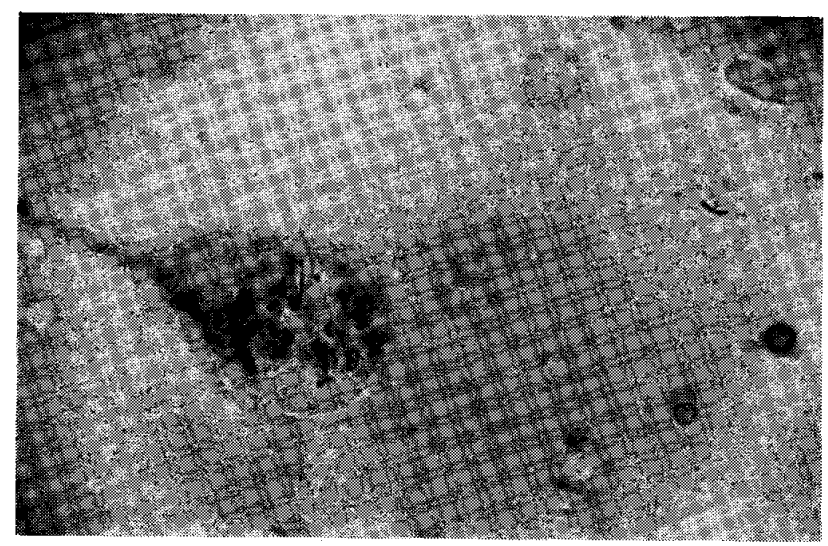

Fig.29 TP -2 minutes.

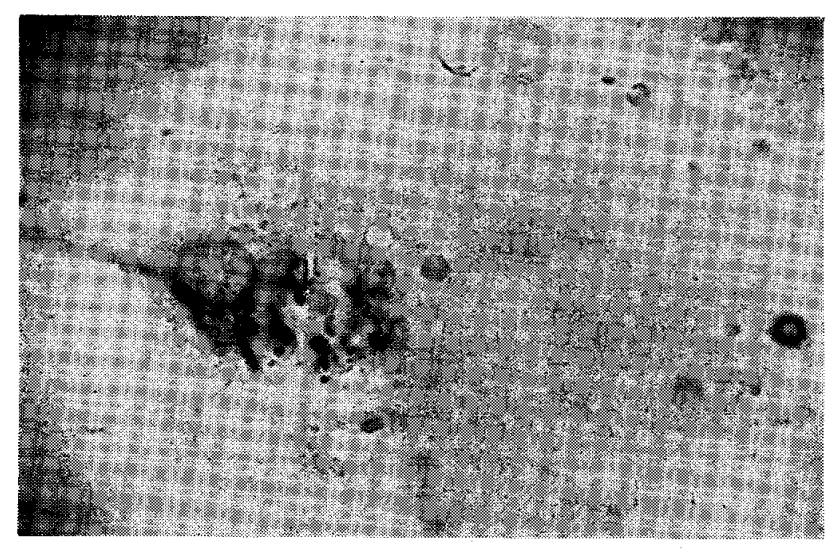

Fig.30 TP -3 minutes.

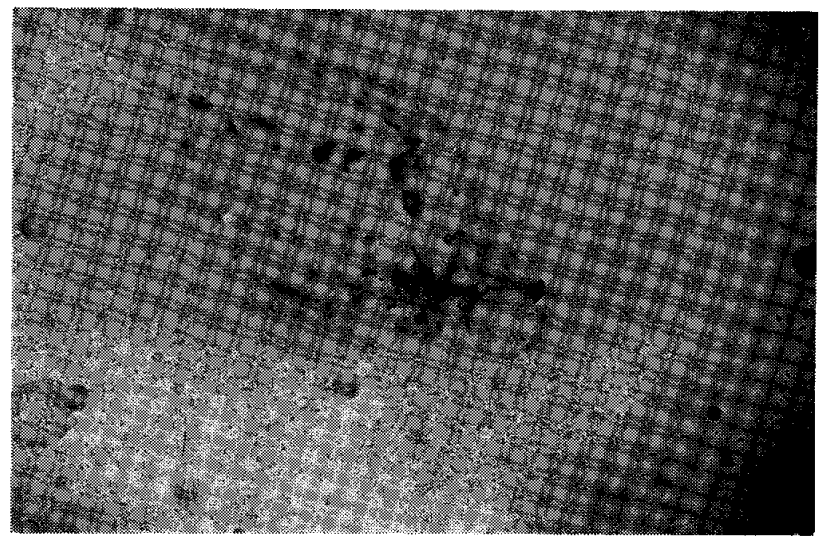

Fig.31 TP -5 minutes.

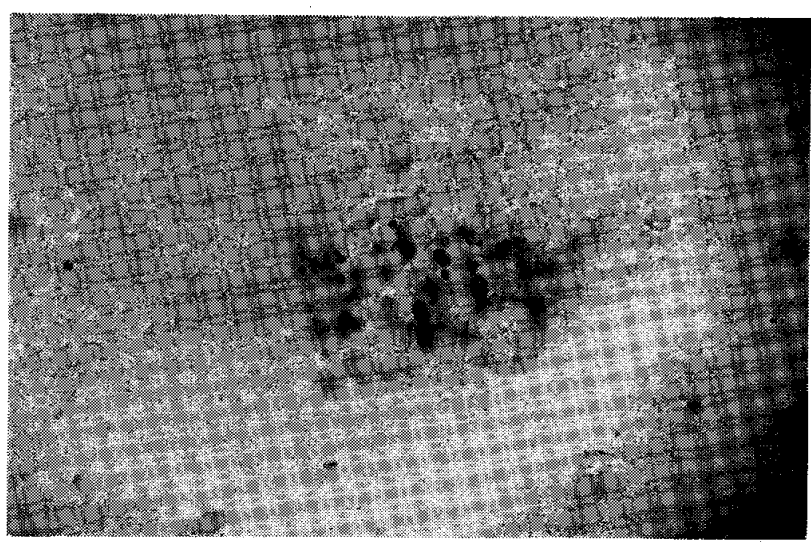

Fig.32 TP -10 minutes.

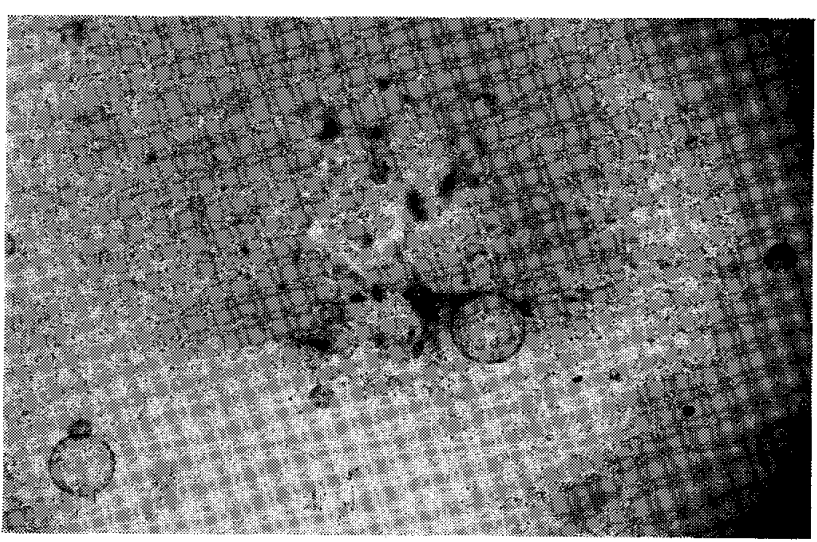

Fig.33 TP-15 minutes. 
心部の不溶性部分の分離が明瞭になり，外層の一部が崩 壊して液中に溶解していくのが観察された，液滴下15分 後には外層は完全に崩壊したが，不溶性部分の形状の変 化は全く認められなかった。

TP, HS試料の変化の状態の模式図を Fig.34 亿示す.
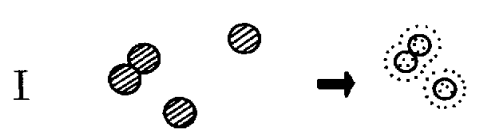

$\dddot{Q}$

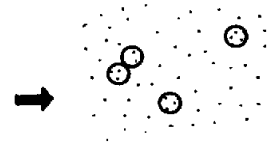

II
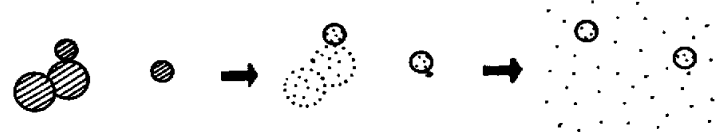

Fig.34 Swelling and dissolution of powder of functional impression materials to its proper mixing liguid.

I : HS powder. II : TP powder.

4）水およびエタノールの検出

ガスクロマトグラフによる分析の結果,各試料とも水, エタノール検出のための溶媒中に含まれるエタノール， アセトンの 4 つの成分のピークがチャート紙上に記録さ れた．水中浸漬時間が長くなるに従い水のピーク面積は 大きくなり，エタノールでは小さくなる傾向を示した．

Table 6 および Fig.35 は練和開始後 5 分の試料に溶 媒 $10 \mathrm{~m} \ell$ を加えてガスクロ分析を行った場合の水とエタ ノールの含有量 $(\%)$ を示す（以後との試料を規準試料 と呼ぶ，てれによると各試料の水の含有量はエタノ一 ル含有量に比べて少なく，試料別では HS試料が最も多 く，TP，TM，VG，HC試料の順に少なくなった。ま たエタノールの含有量は HS, TM, TP, HC, VGの

Table 6 Percents of water and ethanol in solutions of functional impression materials (dissolved $5 \mathrm{~min}$ after mixing).

\begin{tabular}{c|c|c}
\hline \hline & Water $(\%)$ & Ethanol $(\%)$ \\
\hline HS & 2.11 & 4.35 \\
HC & 1.22 & 2.76 \\
VG & 1.27 & 1.72 \\
TP & 1.49 & 3.90 \\
TM & 1.29 & 4.21 \\
\hline
\end{tabular}

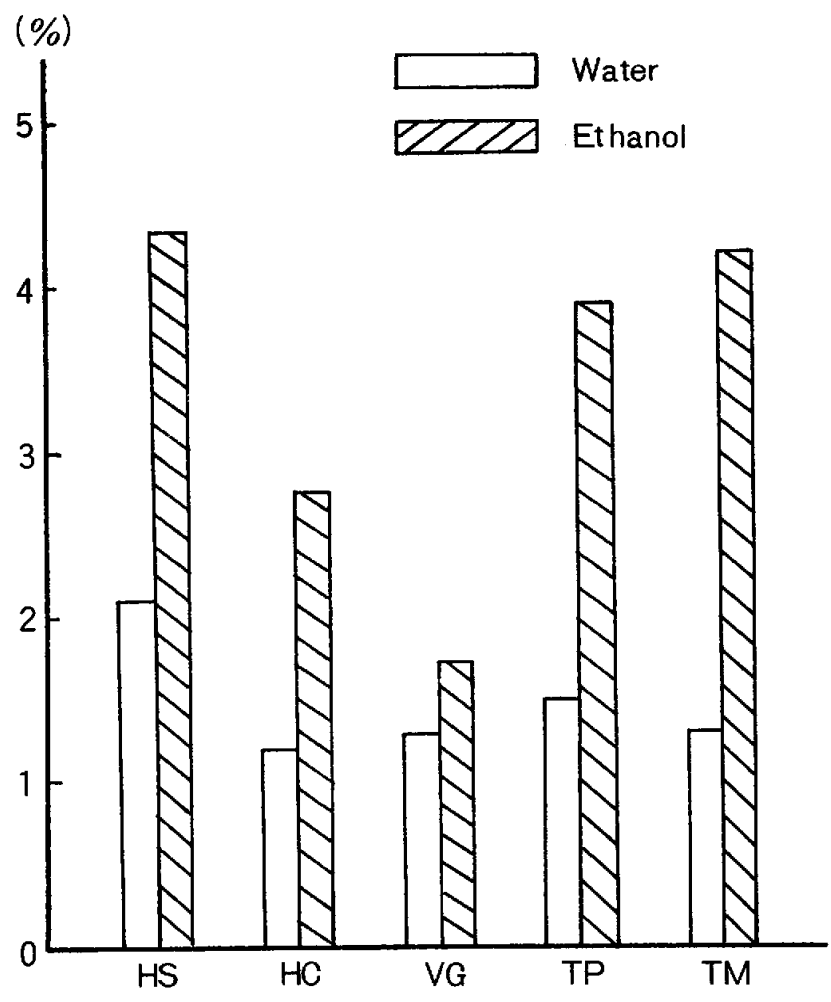

Fig.35 Percents of water and ethanol in solutions of functional impression materials (dissolved $5 \mathrm{~min}$ after mixing).

順に少なくなり，最も多い含有量を示した HS の值は VGのそれに比べて約2.5倍であった（Table 6 ）.

各水中浸漬時間における試料の含水量 $(\%)$ 加ら前述 の水中浸漬をしなかった場合の規準試料の含水量（\%) を差し引いた值を試料の水分吸収量（\%）とした。帛の 結果を Table 7 ならびに Fig.36 に示す。てれによると 各試料とも時間の経過とともに吸水量は増加する傾向を 示した.VG，TP，HSの 3 試料は浸清時間10分から 5 時間（300分）までの吸水量の増加は非常に少ないが，

Table 7 Water absorption (\%) of various functional impression materials.

\begin{tabular}{r|lllll}
\hline \hline $\begin{array}{c}\text { Time } \\
\text { (min) }\end{array}$ & HS & HC & VG & TP & TM \\
\hline 10 & 0.08 & 0.24 & 0.04 & 0.01 & 0.10 \\
30 & 0.09 & 0.35 & 0.07 & 0.04 & 0.14 \\
60 & 0.09 & 0.42 & 0.08 & 0.06 & 0.18 \\
300 & 0.15 & 0.53 & 0.14 & 0.12 & 0.28 \\
1440 & 0.41 & 0.69 & 0.46 & 0.28 & 0.39 \\
4320 & 0.57 & 1.36 & 0.90 & 0.60 & 0.50 \\
\hline
\end{tabular}




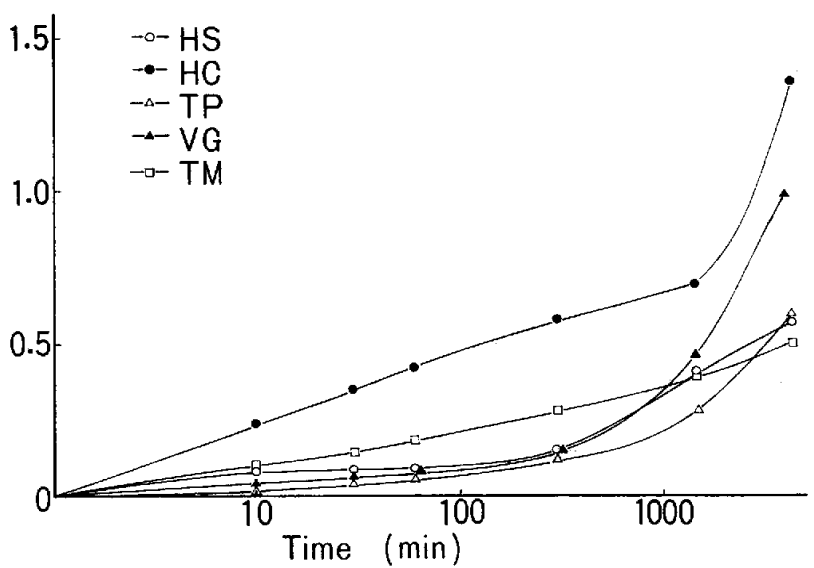

Fig.36 Variation of water absorption with soaking time in water.

それ以後では著しい増加を示した。TM 試料の場合は浸 漬時間 5 時間までは前 3 試料に比べて，やゃ著しい増加 を示したが，その後の増加は少なく, 浸漬時間72時間で はすべての試料のうち最も少ない含水量を示した，HC 試料はすべての試料のうち最も著しい増加を示し, 浸漬 時間72時間目の試料は TM試料の約 3 倍の值を示した. また浸漬時間 5 時間の試料と72時間の試料とを比較する と, $\mathrm{VG}$ 試料では 6.4 倍, $\mathrm{TP}$ 試料では 5 倍, $\mathrm{HS}$ 試料で は3.8倍, $\mathrm{HC}$ 試料では 2.6 倍, TM試料では 1.8 倍に増 加した.

各浸漬時間における各試料と溶媒に含まれるェタノー ル含有量と, 規準試料の場合のエタノール含有量とを比 較し, 各浸清時間によってエタノールが水中に溶出した 量（\%）の変化を Table 8 および Fig.37 亿示す.

これによると各試料とも浸漬時間が長くなるに従い， エタノール溶出量は増加する傾向を示した．その変化は $\mathrm{HC}$ 試料が最も著しく，浸漬時間 72時間 (4320分) では $100 \%$ の溶出を示した. 以下 TM $(85 \%)$, VG $(81 \%)$, TP $(71 \%)$, HS $(52 \%)$ 試料の順に小さくなった.

Table 8 Ethanol elution (\%) of various functional impression materials.

\begin{tabular}{r|rrrrr}
\hline \hline $\begin{array}{r}\text { Time } \\
(\text { min })\end{array}$ & HS & HC & \multicolumn{1}{c}{ VG } & \multicolumn{1}{c}{ TP } & \multicolumn{1}{c}{ TM } \\
\hline 10 & 0.9 & 14.5 & 6.4 & 9.7 & 8.1 \\
30 & 3.2 & 21.7 & 11.0 & 14.1 & 10.0 \\
60 & 5.1 & 26.8 & 15.7 & 16.9 & 16.4 \\
300 & 10.6 & 31.9 & 33.1 & 19.5 & 30.6 \\
1440 & 30.6 & 83.7 & 51.7 & 50.2 & 61.5 \\
4320 & 52.0 & 100.0 & 80.8 & 70.5 & 85.0 \\
\hline
\end{tabular}

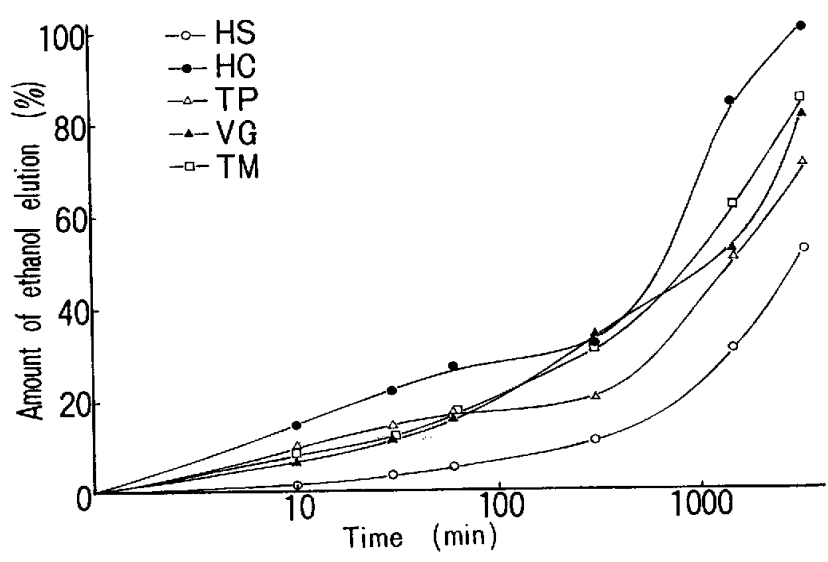

Fig.37 Variation of ethanol elution with soaking time in water.

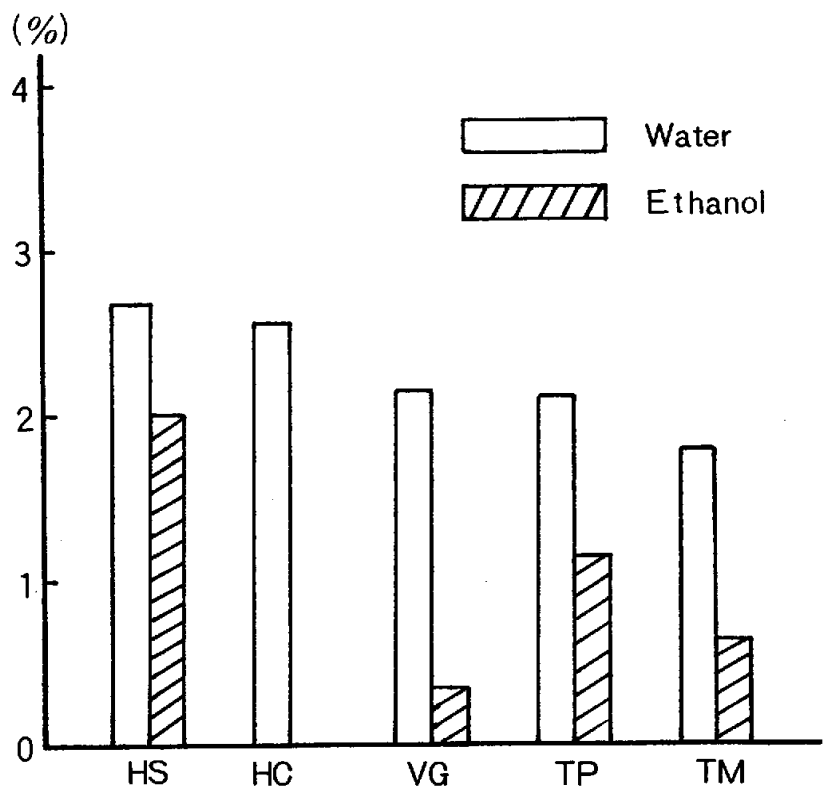

Fig.38 Percents of water and ethanol in solutions of functional impression materials (dissolved 5 min after mixing) at 72 hours from start of soaking in water.

Fig.38 は72時間水中浸漬した場合の各試料と溶媒中 に含まれる水分およびェタノールの含有量（\%）を示 す. 各試料とも水分含有量はエタノール含有量に比べて 多く,規準試料のそれと比べると, $\mathrm{HC}$ 試料では 2.11 倍， VG試料では1.70倍，TP試料では1.40倍，TM試料では 1.39倍, HS 試料では 1.27 倍に増加した。エタノール含 有量はそれぞれ HS 試料 $2.09 \%$ ，TP試料 $1.15 \%$ ，TM 試料 $0.63 \%$, VG 試料 $0.33 \%, \mathrm{HC}$ 試料扔いてはエ夕 ノールは全く検出されなかった。 


\section{IV 考察}

1) 粘度測定について

臨床家の立場から使用しやすい機能的印象材とは，印 象採得時に，患者の日腔内にセットしやすい適度の粘性 を有し，かつセットが完了するまでは粘性，弹性などの レオロジカルな性質の変化が小さい材料である.

HC, VG, HS の 3 試料は TM, TP 試料に比べて公 温 $23^{\circ} \mathrm{C}$ では低粘度を示す時間が比較的長く, 練和開始 から10分経過後においても練和直後の粘度の約10倍にし か変化しない (Fig.11).

豊田 ${ }^{23)}$ は上靧と下顎ではセットに適する印象材の粘 度は異なる、下䫇の義霜の場合，上顎の義蒾の場合に比 べてやや硬く，クリーム状から軟らかい餅状の状態がよ いと述べている．従って，てれらの 3 試料を使用して印 象採得を行う場合には，その操作時間，即ち練和物がク リーム状から軟らかい餅状（粘度では $1.0 \times 10^{6} \mathrm{cp} \sim 2.0$ $\times 10^{6} \mathrm{cp}$ ）に達するまでの時間は著しく長くなることが 子想される。

一方これらの 3 試料の練和物は, 穷团気温度の影響を 受けやすく，温度が高くなると練和開始後でく短時間の うちに著しい粘度上舁がみられるようになる（Fig.12〜 16)。従って HC，VG，HSなどの材料を使用する場合 には，症例に応して練和時の温度を変え，適当な操作時 間にする工夫が必要であろう。

練和物の粘度が $10^{7} \mathrm{cp}$ 亿達するまでの時間之粉液比 の関係では，実験に使用したいずれの試料も粉液比の影 響を受けるが，雾囲気温度が低いほどその影響は大きい

(Fig.17). このことは粉末中への液の拡散によって起 こる膨潤あるいは粉末の一部溶解の結果として生ずる粘 度上昇を考えれば当然のととといえよう。

2）弾性率の測定について

本実験では毎分 12 回のねじり振動を試料に与え，その 時に生じる応力一ひずみの比より弾性率を求めた。これ によると，TP，TM，HC，HS，VG 5 試料とも練和 直後より弾性率の增加がみられたが，中でも口腔内温度 $37^{\circ} \mathrm{C}$ ではVG試料の弾性率の増加が最も著しく, 練和開 始から 60 分後の弾性率は練和後 2 分（患者の口腔内にセ ットする前の時間) でのそれに比べて 346 倍に達した

(Fig.18，19). 乙れ亿対し，HC，TM，TP, HS試料 の弾性率変化は小さく, HC 武料では 19.8倍, TM試料 では 6.3 倍, TP試料では 6.0 倍, HS 試料では 4.7 倍と なった．促って本実験に使用した 5 試料の中では，VG 試料が最も弾性に富む粘弾性体に変化するといえる。ま
た練和開始から60分後の弾性率では TP 試料が最も大き い值 $49.7 \times 10^{4} \mathrm{dyne} / \mathrm{cm}^{2}$ を示し,VG試料では $41.5 \times$ $10^{4} \mathrm{dyne} / \mathrm{cm}^{2}, \mathrm{HC}$, TM, HS試料ではそれぞれ 22.4 $\times 10^{4}$ dyne $/ \mathrm{cm}^{2}, \quad 21.0 \times 10^{4} \mathrm{dyne} / \mathrm{cm}^{2}, \quad 17.5 \times 10^{4}$ dyne $/ \mathrm{cm}^{2}$ となった。このととから 60 分後の見かけの 硬さは TP試料の場合が最も大きいといえるが，試料が 口腔内という特殊な条件下で使用される場合を考慮する と，本実験だけで結論づけることは非常に困難なように 思われる．Fig.20は練和物の弾性率がもっとも変化し はじめる時間を知るために Fig.19 をそれぞれ図上微分 し, 練和後の時間に対して弾性率の変化率 $\left\{\frac{\mathrm{d}\{\mathrm{G}(\mathrm{t})}{\mathrm{dt}}\right\}$ をプロットしたものである。乙れによると弾性率の堌加 が最も著しい時間はHS, TM試料が最も早く ( 2 分), 次いで TP (3 分), HS (3.5分), VG (6 分) 試料の 順で遅くなった（Fig.20）。従って一度口腔内に装着し たものにおいては HS，TM 試料では装着後 2 分， TP 試料では 3 分, $\mathrm{HC}$ 試料では 3.2 分, $\mathrm{VG}$ 試料では 6 分経 過しないうちに口腔外に撤去してトリ之ング等の操作を 行うことは避けるべきであろう。

機能的印象材を練和し，患者の口腔内にセットするま での操作時間を15分以上必要とする症例はほとんど考え られないため，15分後での弾性率を求め， $23^{\circ} \mathrm{C}$ と $37^{\circ} \mathrm{C}$ の場合を比較した（Fig.21）。乙れによると，いずれの 試料も弾性率の温度依存性は著しいが，中でもVG試料 がとくに著しいととがわかる。

\section{3）顕微鏡による観察について}

字験 $1 ， 2$ で材料の粘度上昇, 弾性率の増加の現われ 方に材料間でかなりの差があることがわかった。そのた め粘度変化が比較的大きく弾性率の最も高い $\mathrm{TP}$ 試料 と, 粘性, 弾性ともに変化が少ない HS 試料について 顕微鏡下で粉末の膨潤あるいは溶解の状態を観察した

(Fig.22〜33)。乙れによると TP試料は液に非常に溶 解しやすい粉末粒子と，膨潤や溶解を起しにくいわずか の微粉末粒子のブレンドであることがわかった．液滴下 後15分では溶解性のある粉末は完全に溶解し，不溶性の 微粉末粒子をとりまく組織のものになるととがわかっ た。これに対し，HS 試料では粉末粒子は中心部に不溶 性の部分と，それをとりまく可溶性の部分から成ってい ることがわかった。いずれのタイプも練和後十分時間が 経過した後は同様な組織のゲルを形成するが，練和初期 では, 可溶性部分の溶解速度の苃異が，粘度上昇，弾性 率の増加の差異を引き起す結果になったものと考えられ る. 
4) 水分, エタノールの検出について

機能印象の採得は常に材料が口腔涶液に浸漬された状 態で行われる，従って材料に適度の可塑性を与えるため に加えられているエチルアルコールあるいはその他の可 溶性成分は赜液中にとけ出し，さらに外部より菳液の混 入なども加わり，奏際では空気中で行う実験結果とかな り買った挙動を示すことが予想される．そこで練和開始 から5 分後の試料に水, エタノールの検出のための溶媒 (アセトン $90 \%$ ，メタノール10\%) を一定量 $(10 \mathrm{~m} \ell)$ を加え, 試料と溶媒中に含有する水とエタノール含有量 を求めた (Fig.35). この含有量を規準にして, 各試料 をそれぞれ一定時間水中浸漬した試料について規準試料 の場合と同様に, 試料と溶媒中に含まれる水, エタノ一 ルの含有量の変化を調べた（Fig.36，37）。乙れによる と，単に試料を水中 $\left(37^{\circ} \mathrm{C}\right)$ に浸漬しているだけで式 料中への水の混入，アルコール分の溶出が生じているこ とがわかる．Fig.38は72時間水中浸漬した場合のグラ フであるが, $\mathrm{HC}$ 試料ではアルコール成分が全く検出さ れなくなる状態にまで変化した，72時間浸漬後の水分合 有量は規準試料のそれに対して，HC試料では2.11倍と なり最も大きく，VG 試料では 1.70 倍，TP 試料では 1.40倍, TM試料では1.39倍, HS 試料では1.27倍とな った. 奏際の臨床的な条件下では咀嚼圧も加わるため， 72 時間よりも短時間の内にこの傾向は生じるものと予測 される。従って，乙れらの材料を使用する場合（特に HCの場合), 七ット後72時間にはセット後比較的短時間 の内に見られるような挙動は期待できないことが予測さ れる。

臨床では材料がセットに適した粘度を示すようになる までの時間が長い材料に対しては，微温湯に浸すことに より，その操作時間を調節する方法をとるが，可溶性部 分が完全に溶解し均一な組織になる以前に微温湯に浸漬 して操作時間を短縮するととは材料中の成分をより容易 に溶出させる結果となり，材料の物性の立場からあまり 好ましい方法とはいえないように思われる。

\section{$\mathrm{V}$ むす び}

近年，機能的印象材は，組織調整と機能印象採得を同 時に行えるものとして臨床に好んで使用されるようにな った。しかし，その物理的，機械的な性質については不 明な点が多い，そてで著者は 5 種の市販機能的印象材に ついて粘度および弾性率の経時的変化の測定, 粉末が練 和液を含んで膨潤し，溶解する状態の顕微鏡による観 察，さらに練和物中に含まれる水分とエタノールをガス
クロマトグラフにより検出した。その結果，次のような 結論を得た。

1. HS, HC, VGの操作時間は TP, TMより長く, その閒の粘性, 弾性率の変化は小さかった。

2. 実験仁供したすべての材料の操作時間は雱囲気温 度や粉液比の影響を受け，雲囲気温度を高くするか，粉 液比 $(\mathrm{P} / \mathrm{L})$ を大きくするととにより操作時間は短縮さ れた。

3. 口腔队温度 $\left(37^{\circ} \mathrm{C}\right)$ における練和開始後 60 分の 弾性率は TP では $49.7 \times 10^{4} \mathrm{dyne} / \mathrm{cm}^{2}, \mathrm{VG}$ では 41.5 $\times 10^{4}$ dyne $/ \mathrm{cm}^{2}$, HC では $22.4 \times 10^{4} \mathrm{dyne} / \mathrm{cm}^{2}$, TM では $21.0 \times 10^{4} \mathrm{dyne} / \mathrm{cm}^{2}$, HS では $17.5 \times 10^{4}$ dyne $/ \mathrm{cm}^{2}$ であった。

4. 口腔内温度 $\left(37^{\circ} \mathrm{C}\right)$ にセット後は, すべての材 料において, その直後上り粘性, 弾性の著しい上昇を示 し，その反応は約 6 分以内にピークに達して $20 \sim 40$ 分に は，ほぼ安定した。

5. 機能的印象材の粉末は練和液に対して, 可溶性の 粒子と不溶性の粒子ょり構成されるタイプと，すべての 粉末粒子が可溶性の部分と不溶性の部分から成るタイプ のものとがあった。

6. 練和物の物性の変化が早い機能的印象材ほど, 練 和液中に粉末粒子が膨潤あるいは溶解する現象が早くあ らわれた。

7. 奏験に供したすべての材料では，蒸留水に浸漬す ることにより水分を吸収し，エタノールを溶出するが， その量は浸漬時間の増加に従って多くなった。

稿を終わるにあたり，本研究に終始琶切な御指導と御 校閲を賜った恩師豊田静夫教授に深甚な感謝の意を表わ すとともに, 実験上数多くの御教示をいただいた理工学 教室林一郎教授ならびに井上勝一郎助教授に蝉心より謝 意を捧げます．また本研究に種々御協力をいただいた理 工学教室, 補釉学教室員の皆さまに対し, 心から謝意を 表わします。

\section{引用 文 献}

1. 平田幹男：無荬顎粘膜の被圧縮度に関する臨床的研 究, 補緅誌, $3: 14-27,1959$.

2. 大島健嗣：総義霜床座粘膜の被圧縮時における荷重 量および圧縮量に関する研究, 補経誌, 12 ： $31-72,1968$.

3. 宮下恒太 : 顎粘膜の局所被圧変位度と咬合力による 義㐘床の沈下度とに関する研究, 歯科学報, 70 
: 38-68, 1970 .

4. Tench, R.W. : Afterthoughs concerning impressions for full dentures, J. Amer. Dent. Ass. 15:37, 1928.

5. Tench, R. W. : Impression for dentures, J. Amer. Dent. Ass. 21: 1005, 1934.

6. Addison, Pavl I : Mucostatics impression, J. Amer . Dent. Ass. 31:941-946, 1952.

7. Tilton, G. E. : A minimun pressure complete denture impression technique, J Posthet. Dent. 6(1): 6-23, 1956.

8. Apploby, R. C. : A mandibular impression technique for displacement tissue, $J$. Prosthet. Dent. $4: 335,1954$.

9. 佐久間孔毅：無籴䫇印象採得のレオロジーによる検 討, 歯科器誌, $12 ： 79-124,1965$.

10. Lytle, R. B. : The management of abused oral tissues in complete denture construction, J. Prosthet. Dent. $7: 27-$ $42,1957$.

11. Lytle, R. B. : Complete denture construction based on a study of the deformation of the underlying soft tissue, J. Prosthet. Dent. $9: 539-551,1959$.

12. Lytle, R. B. : Soft tissue displacement beneath removable partial and complete dentures, J. Prosthet. Dent. 12:3443,1962 .

13. Chase, W. W. : Tissue conditioning using dynamic adaptive stress, J. Prosthet. Dent. $11: 804-815,1961$.

14. Vig, R. G. : A modified chew-in and functional impression technique, J. Prosthet. Dent. 14:214-220, 1964.

15. Pound, E. : Conditioning of denture $\mathrm{Pa}-$ tients, J. Amer. Dent. Ass. $64: 461$, 1962 .

16. Pound, E. : Preparatory dentures, J. Prosthet. Dent. 28: 5-18, 1968.

17. Tassarotti, B. : A clinical and histologic evaluation of a conditioning material, J. Prosthet. Dent. 28:13-18, 1972.

18. Tucker, K. M. : Relining complete denture with the use of a functional impression,
J. Prosthet. Dent. 16:1054-1057,1966.

19. Watson, R. M. : The use of tissue conditioner for obuturator impression, Brit. Dent. J. 124 ( 5) : 226, 1968.

20. von Krammer, K. : Tissue conditioner, J. Prosthet. Dent. 25:244-250, 1971.

21. 松本直之一小田 稔・他：いわりる Dynamic Impression Material による粘膜の修復効 果について, 補緅誌，6：234-239，1962.

22. 松元 誠 - 梶井 徽: Dynamic impression material によって前米義雬の口蓋形態を機能的 に改善した 1 症例,補経誌， $10: 75 \sim 78 ， 1966$.

23. 豊田静夫：リベースの時期と方法, 日本䨑科評論, $427: 43-53,1978$

24. 清水 稔・豊田静夫・他：ダイナミック印象法を忍 用した上顎金属床義歯について，九州歯会誌， 32 (6) : 852-856, 1979.

25. 田中資郎：口蓋粘膜のクリープに関する研究, 補緅 誌, $16 ： 358-379,1973$.

26. 中禹俊朗：口蓋粘膜の応力緩和に関する研究, 補経 誌, $19 ： 391-410,1975$.

27. 三輪英則：断続荷重による口蓋粘膜のクリープ, 補 経誌，20：399-422，1976。

28. Braden, M. : Tissue conditioners. I . Composition and structure. J. Dent. Res. $49: 145-148,1970$.

29. Braden, M. : The composition, structure and flow properties of functional impression naterials (tissue conditioners), Dent. Pract. $16: 301-304,1966$.

30. Wison, H. J., Tomlin, H. R. et al. : Tissue conditioners and functional impression materials, Brit. Dent. J. 121:9-16, 1966.

31. Braden, M. : Tissue conditioners. III. Water immersion characteristics, J. Dent. Res. $50: 1544-1548,1971$.

32. Stracke, E. N., Marcroft, K. R., et al. : Physical properties of tissue conditioning materials as used functional impressions, J. Prosthet. Dent. 27:111-119, 1972 .

33. MeCarthh, J.A., and Moser, J.B.: Mechanical properties. Part I. : Theoretical 
considerations, behavical characteristics, and tensil properties, J. Prosthet .

Dent, $40: 89-97,1978$.

34. McCarthy, J.A. and Moser, J. B. : Undercut reproducibility of functional impression materials (tissue conditioners), J. Oral. Rehab. $5: 287-292,1978$.

35. McCarthy, J. A. and Moser, J. B. : Mechanical properties of tissue conditioners Part II : Creep characteristics, J. Prosthet. Dent. $40: 334-342,1978$.

36. Ward J. E. : Effect of time lapse between mixing and loadig on the flow of tissue conditioning materials, J. Prosthet. Dent. $40: 499-508,1978$.

37. Braden, M. : Tissue conditioner . II . Rheologic properties, J. Dent. Res. $49: 496$ $-501,1910$.

38. 川上道夫・竹花庄治 : Dynamic impression material のクリープとその回復，歯理工誌， 6 (10) : 7-11, 1965 .

39. 関根篤治 - 他：動的印象材の粘弾性についての基礎 的検討，粜科学報， $68: 1059-1070,1968$.

40. 佐藤鎮城：機能印象材の粘弾性に関する基礎的研 究, 九歯会誌, 26 (4) : 334-348, 1971.

41. 三輪英則・服部正己・他：動的ならびに合成ゴム印
象材のクリープに関する研究, 補緅誌, 20 : 393-398, 1976.

42. 浜野 光・光永マサ子: 涙液の粘度測定, 日本眼科 紀要，24（4）：435-444，1973.

43. Bovis, S. C., and Wilson, H. J.: Setting characteristics of composite filling materials, Brit. Dent. J. 131:352-356, 1971.

44. Inoue, K. and Wilson, H. J. : Viscoelastic properties of elastometric impression material (Part1), J. Oral Rehab. 5 : 89-94, 1978 .

45. Inoue, K. and Wilson, H. J. : Viscoelastic properties of elastometric impression material (Part 2), J. Oral Rehab. 5 : $261-267,1978$.

46. 井上勝一郎・林一郎・他 : 弾性印象材に関する基 礎的研究 (第 3 報), 霜理工誌, 19 (45)：48一 $52,1978$.

47. 井本立也著：概説レオロジ一, 東京化学同人, 1963 .

48. 吉識雅夫 - 金沢武著：材料力学明解,養賢堂, 1967 .

49. 鵜戸口英善・国尾武沢：チモシェンコ材料力学, 東 京図書 1962 .

50. 松隈昭著：ガスクロマトグラフィーの実際, 東京化 学同人, 1978 . 